University of the District of Columbia School of Law

Digital Commons @ UDC Law

Journal Articles

Publications

$10-4-2016$

The One-Year Bar to Asylum in the Age of the Immigration Court Backlog

Lindsay M. Harris

Follow this and additional works at: https://digitalcommons.law.udc.edu/fac_journal_articles

Digitadrt of the Immigration Law Commons, and the International Humanitarian Law Commons Commons

Network

Logo 


\title{
THE ONE-YEAR BAR TO ASYLUM IN THE AGE OF THE IMMIGRATION COURT BACKLOG
}

\begin{abstract}
LINDSAY M. HARRIS*
Imagine being forced to flee your home, separated from your children, and undergoing the perilous journey to seek safety and protection in the United States. Upon arrival, you are immediately detained and questioned about your intentions. You explain that you fear for your life and seek asylum protection. You may even undergo a detailed interview with an asylum officer, who finds that you have a significant possibility of establishing asylum eligibility. You are released from detention to pursue your asylum claim in immigration court. You diligently attend check-ins with an Immigration and Customs Enforcement officer for the next two years but struggle to find affordable legal representation as you await your first court date-scheduled two years after your arrival. When you appear at that court date, without an attorney, you learn for the first time that you were required to file an application for asylum with the immigration court within one year of your arrival. Your failure to do so bars you from asylum eligibility. You are now only eligible for a lesser form of relief and will live in limbo-you will never be reunited with your children who remain in danger in your home country, you can never travel abroad, and you will never become a permanent resident or a United States citizen.

This absurd situation, faced by thousands of asylum seekers navigating our complex immigration system alone, results from the disastrous interplay of a twenty-year-old law barring asylum for those who do not file within one year of arrival, and an immigration court backlog rendering compliance virtually impossible. Our immigration courts are overwhelmed, with over 521,000 cases pending and a wait, on average, of almost two years for an initial court hearing. More than half of the recently arrived asylum seekers, largely women and children fleeing violence in Central America, lack legal representation. The United States Government provides no notice to asylum seekers of the one-year bar, practically denying all but those with competent legal counsel a meaningful opportunity to file within one year.

Drawing upon contemporary cases, this Article is the first to illuminate the human costs of the one-year bar to asylum in this age of unprecedented immigration court backlog: needless deprivation of rights
\end{abstract}

* Assistant professor of law at the University of the District of Columbia's David A. Clarke School of Law, teaching in the Immigration and Human Rights Clinic. The Author wishes to thank colleagues and Professors Kristina M. Campbell, Matthew Fraidin, Laila L. Hlass, Marcy L. Karin, Philip G. Schrag, Andrew I. Schoenholtz, and Sarah Sherman-Stokes for their thoughtful suggestions and insights. I am also indebted to attorneys Dree Collopy, B. Shaw Drake, Mary Kenney, and Brian R. Israel, along with UDC law student Isabel Toolan. Special thanks go to retired immigration judge and former Board of Immigration Appeals Chairman, Paul Wickham Schmidt for sharing his insight. Thank you to UDC-DCSL for funding to support this Article. This Article also benefited from valuable feedback from participants at the 2016 New York University School of Law's Clinical Law Review Writers' Workshop. All errors are my own. 
and full protection for vulnerable children and families seeking protection in the United States. It is also the first to analyze the Executive Office for Immigration Review's recent attempt to solve this problem for asylum seekers represented by legal counsel. In doing so, the Article lays out a detailed road map of complementary reforms and actions by each actor in the immigration system necessary to ensure access to justice-specifically, to provide a fair and meaningful opportunity to apply for asylum for all asylum seekers.

Introduction

I. Asylum and the One-Year Filing Deadline .................... 1190

A. Paths to Seeking Asylum ............................ 1190

B. The Origins of the One-Year Bar to Asylum ............. 1192

C. Operation of the One-Year Deadline to Bar Protection for Genuine Refugees ............................... 1196

D. Why Withholding of Removal and Relief Under the Convention Against Torture are Inadequate ............ 1200

II. Immigration Court Backlog \& A Crisis of Representation ....... 1204

A. Immigration Court Backlog .......................... 1204

B. A Crisis in Legal Representation of Asylum Seekers ..... 1208

III. The Current Situation: An Incomplete Solution Deepens the

Divide Between Represented and Pro Se Asylum Seekers ... 1213

A. The EOIR Changes its Policy and Now Allows Filing of Asylum Applications at the Court Window ............. 1213

B. Case Studies of Asylum Seekers Barred from Protection by the Deadline and Backlog ........................ 1217

1. Salvadoran Survivor of Domestic Violence Barred from Asylum in Baltimore ..................... 1217

2. Honduran Survivor of Domestic Violence Barred from Asylum in Texas ........................... 1221

C. Federal Court Challenge to the Lack of Notice and Opportunity to File ............................... 1224

IV. Potential Solutions......................................... 1226

A. Reforms to Address the One-Year Filing Deadline ....... 1227

B. Reforms to Reduce the Immigration Court Backlog...... 1227

1. More Prosecutorial Discretion by DHS ............. 1227

2. Further Increase the Number of Immigration Judges and Judicial Law Clerks ............................ 1230

3. Empower USCIS to Adjudicate Asylum Cases Originating from Positive Credible Fear

Determinations 1231

C. Reforms to Specifically Address the Interplay of the One-Year Bar and the Backlog....................... 1232

1. Department of Homeland Security .................. 1232

a. Expand the List of Extraordinary Circumstances. 1232

b. Include a Limited Exception to the Deadline for 
Those Without Notice.

2. United States Citizenship and Immigration Services . 1235

a. Mandate a One-Year Bar Advisal for Asylum

Seekers with Positive Credible Fear

Determinations

3. Executive Office for Immigration Review

a. Provide Advisals Following Positive Credible

Fear Interviews and at the First Scheduled

Master Calendar Hearing.

b. Implement a Limited Exception for Lack of

Notice and Expand Exceptions to the One-Year

Deadline....

c. Provide Maximum Due Process for

Unrepresented Asylum Seekers

4. ICE Assistant Chief Counsel...

5. Immigration Attorneys and Advocates:

a. Argue that Undergoing a Credible Fear Interview

Constitutes Filing for Asylum.................. 1244

b. Increase Legal Representation of Asylum Seekers 1245

c. Outreach and Information Sharing with Asylum

Seekers ........................................ 1249

Conclusion.

\section{INTRODUCTION}

This Article addresses the disastrous interplay between the overburdened immigration court system and the one-year deadline to apply for asylum for individuals fleeing persecution and seeking protection in the United States. ${ }^{1}$ Currently, 291 immigration judges nationwide are tasked with the adjudication of over 521,000 immigration cases. $^{2}$ The number of individuals seeking asylum

1. An asylum applicant is referred to as an "asylum seeker." Once granted asylum, the asylum seeker becomes an "asylee." Asylees and refugees must meet the same legal definition of "refugee" under 8 U.S.C. § 1101(a)(42)(A) (2012) (a refugee is "any person who is outside any country of such person's nationality . . . and who is unable or unwilling to return to, and is unable or unwilling to avail himself or herself of the protection of, that country because of persecution or a well-founded fear of persecution on account of race, religion, nationality, membership in a particular social group, or political opinion"); see 8 C.F.R. § 1208.14(a)-(b) (2016).

2. Press Release, Exec. Office for Immigration Review, Executive Office for Immigration Review Swears in Fifteen Immigration Judges, U.S. DEP'T OF JusTICE (Sep. 26, 2016), https://www.justice.gov/eoir/pr/executive-office-immigration-reviewswears-15-immigration-judges [https://perma.cc/E7H6-ED54]; Alicia A. Caldwell, Federal Immigration Court Backlog Tops 500,000 Pending Cases, Associated PREss: THE BIg STORY (July 20, 2016), http://bigstory.ap.org/7b1dc1cdb32740d18ad9c658ebce5f43\&utm_source = android_app 
protection is at a record high. ${ }^{3}$ A humanitarian crisis in the Central American countries of Guatemala, Honduras, and El Salvador has resulted in unprecedented numbers of unaccompanied children and families seeking protection in the United States. ${ }^{4}$ Any failure by these asylum seekers to file their applications within one year of arrival, as required by a two-decade-old law aimed at addressing asylum fraud, ${ }^{5}$ often results in an outright bar to asylum. In a tragic twist of form over substance, worthy asylum seekers are denied the protection of asylum by an impossible procedural hurdle.

While scholarly critiques of the one-year deadline itself abound, the unanticipated effect of the immigration court backlog remains unexplored. ${ }^{6}$ Using accounts of contemporary cases, this Article is the first to illuminate the human costs of this twenty-year-old misguided law in this age of unprecedented immigration court backlog: the deprivation of rights and full protection for vulnerable children and families seeking protection in the United States.

As this Article was going to print, the Executive Office of Immigration Review (EOIR), within the Department of Justice, announced a policy change that will help to remedy this problem for asylum seekers represented by competent counsel. ${ }^{7}$ Specifically, the

\&utm_medium $=$ mail\&utm_campaign $=$ share

[https://perma.cc/RMT5-PZRQ]

(reporting that according to EOIR, there are now 500,051 cases in the backlog); Backlog of Pending Cases in Immigration Court as of September 2016, TRAC IMMIGRATION, http://trac.syr.edu/phptools/immigration/court_backlog/ [https://perma.cc/LQ5R-U96A] (last visited Nov. 10, 2016) (reflecting that 521,676 cases are currently pending in immigration court).

3. United Nations High Comm'r for Refugees, Global Trends: Forced DISPLACEMENT IN 2015, at 3 (2016).

4. JonAthon T. Hiskey ET AL., Am. IMMigration Council, Understanding the Central AMERICAN Refugee Crisis 1 (2016).

5. 8 U.S.C. $\S 1225($ b)(1)(A)(i) (2012); see id. $§ 1225$ note (GAO Study on Operation of Expedited Removal Procedures).

6. The phenomenon was mentioned in a detailed report to the Administrative Conference of the United States in 2012, but has not been explored in depth. Lenni B. Benson \& Russell R. Wheeler, Enhancing Quality and Timeliness in Immigration Removal Adjudication, 41 (draft report prepared for the consideration of the Administrative Conference of the United States) (June 7, 2012), https://www.acus.gov/sites/default/files/documents/Enhancing-Quality-and-Timelinessin-Immigration-Removal-Adjudication-Final-June-72012.pdf [https://perma.cc/A3DDKXF4] ("We also heard some anecdotal reports that in Texas and several other courts, individuals who are subject to expedited removal seek protection at the border, are paroled (released from detention) into the U.S. and pass a credible fear interview yet missed the one year filing deadline because the busy immigration courts could not hear their cases within the time deadline. These pro se applicants did not know they needed to press the court for an earlier hearing date due to the court's rule requiring both a hearing to allow the in-person filing of an application for asylum.").

7. Memorandum from Michael C. McGoings, Chief Immigration Judge (Acting), U.S. Dep't of Justice, to All Immigration Judges et al. (Sept. 14, 2016), 
Chief Immigration Judge issued a memorandum instructing immigration judges to find that asylum applications filed at the court window, rather than in open court, should be considered filed for the purposes of meeting the one-year filing deadline. ${ }^{8}$ Thus, an asylum seeker who has knowledge that she does not have to wait to file their asylum application at her court hearing, which may be scheduled more than a year into the future, can preserve her asylum eligibility by filing her asylum application at the court window. If followed by corresponding reforms from the United States Citizenship and Immigration Services (USCIS) and further EOIR action, the recent EOIR policy change could form part of a constellation of solutions for a significant portion of asylum seekers. Absent additional reforms, however, the policy change risks deepening the unfair disparity in treatment of represented and unrepresented asylum seekers. Asylum seekers without counsel remain at risk of losing their asylum eligibility en masse. This disaster in the making is as avoidable as it is unjust, and this Article presents road maps for each actor in the immigration system to prevent serious consequences for asylum seekers.

Part I offers a brief overview of the asylum system in the United States, examines the creation of the one-year bar twenty years ago, explores prior critiques of the bar, and explains why asylum relief is so important. Part II surveys the current state of our overwhelmed immigration court system and explains the current crisis of legal representation for asylum seekers. Part III analyzes the recently issued EOIR policy change, modifying the mechanics for filing an asylum application in immigration court, and explains how this change fails to ensure the rights of pro se asylum seekers, offering two case studies of asylum seekers barred from asylum by the interplay of the backlog and the one-year bar. Part III also explains the measures attorneys were previously taking to protect their clients and the pending class action lawsuit aiming to hold the various government agencies accountable for the failure to remedy this problem. Finally, Part IV proposes a complementary set of solutions to this mounting crisis, identifying actions within reach of each actor in the immigration system. Part IV ultimately argues that EOIR and USCIS must undertake further administrative and regulatory reforms to ensure that all asylum seekers, whether represented by competent counsel or pro se, have a meaningful opportunity to meet the one-year filing deadline.

https://www.justice.gov/sites/default/files/pages/attachments/2016/09/14/oppm_1601.pdf [https://perma.cc/39FN-ZRYV].

8. $\quad I d$. 


\section{ASYLUM AND THE ONE-YEAR FILING DEADLINE}

\section{A. Paths to Seeking Asylum}

Asylum seekers are individuals forced to flee their countries because they fear or have suffered persecution on account of their race, religion, nationality, political opinion, or membership in a particular social group. ${ }^{9}$ There are three distinct paths to seeking asylum in the United States. The first is known as "affirmative" asylum, meaning that an individual is already within United States' borders and takes the initiative to affirmatively file an application for asylum. These individuals may be undocumented, living in the United States without status, or often they have entered on a visa, a tourist or student visa for example, which has or will expire. USCIS adjudicates these affirmative asylum claims through a non-adversarial interview with an asylum officer at one of eight asylum offices or sub-offices nationwide. ${ }^{10}$ The asylum officer may grant the asylum application, or refer an undocumented individual to immigration court for removal proceedings, where they may continue to pursue their application for asylum before an immigration judge.

The second path to seeking asylum is where an individual is already living within the United States and is placed into "removal proceedings" and files her application as a defense to deportation from the country before an immigration judge in immigration court, under the EOIR. ${ }^{11}$

The third path-really a subset of defensive claims, but a category that merits mentioning in its own right-includes the increasing numbers of individuals subjected to "expedited removal." Congress created the expedited removal system, along with the one-year deadline, in $1996 .^{12}$ In general, the expedited removal system is intended to allow for a streamlined removal process for recent entrants at or near the border. The use of expedited removal has rapidly

9. The Immigration and Nationality Act defines a refugee as:

[A]ny person who is outside any country of such person's nationality . . . and who is unable or unwilling to return to, and is unable or unwilling to avail himself or herself of the protection of, that country because of persecution or a well-founded fear of persecution on account of race, religion, nationality, membership in a particular social group, or political opinion.

Immigration and Nationality Act (INA) of $1965 \S$ 101(a)(42)(A), 8 U.S.C. $\S$ 1101(a)(42) (2012).

10. 8 C.F.R. $\S 1208.4(b)(1),(2)$, (5) (2016).

11. Id. $\S 1208.4(\mathrm{~b})(3)-(4)$.

12. 8 U.S.C. $\S 1225(\mathrm{~b})(1)(\mathrm{A})(\mathrm{i})$, (B)(iii)(I) (2012) (setting up the expedited removal system). 
expanded since its initial implementation. Originally, expedited removal was only implemented at ports of entry, but expanded to beyond the border in $2004 .{ }^{13}$ Now, expedited removal proceedings may be applied to individuals who are apprehended within one hundred miles of the border and are unable to establish that they have been continuously physically present in the United States for the preceding fourteen-day period. ${ }^{14}$

Upon encountering individuals and families who have entered the United States, often without inspection, or who have asserted their claim for asylum at a border patrol station, United States Department of Homeland Security (DHS) places many of them into the expedited removal fast-track removal process. ${ }^{15}$ Where an individual expresses a fear of return to their home country or an intention to apply for asylum, however, she must be referred for a "credible fear interview" with an asylum officer. ${ }^{16}$ During this credible fear interview, an asylum seeker must establish a significant possibility that she will establish eligibility for asylum. ${ }^{17}$ Often, she must do so without an attorney because immigrants do not have a right to a government-appointed attorney in immigration proceedings, ${ }^{18}$ although they may hire one at their own cost or through pro bono services. If the asylum officer determines that the individual has a significant possibility of establishing eligibility for asylum, the asylum officer issues charging documents, in the form of a "Notice to Appear" (NTA) and places the asylum seeker into regular removal proceedings, where she may apply for asylum as a defense to removal. ${ }^{19}$ In recent years, the government has used expedited removal with greater frequency; indeed, the number of credible fear interviews generated by expedited removals has increased from 5,523 conducted in 2009 to over 65,000 just in the first nine months of the 2016 fiscal year. $^{20}$

13. In 2004, Congress passed the Intelligence Reform and Terrorism Prevention Act of 2004, Pub. L. No. 108-458, § 7210(d)(1), 118 Stat. 3852 (codified as amended at 8 U.S.C. $\S 1225 \mathrm{a}(\mathrm{a})(4))$.

14. Designating Aliens for Expedited Removal, 69 Fed. Reg. 48,877 (Aug. $11,2004)$.

15. 8 C.F.R. $\S 1235.3$ (b)(ii)-(iii) (2016).

16. 8 U.S.C. $\S 1225($ b)(1)(A)(ii); 8 C.F.R. $§ 253.3(b)(4)(2016)$.

17. 8 U.S.C. $\S 1225(\mathrm{~b})(1)(\mathrm{B})(\mathrm{v})$.

18. United States v. Reyes-Bonilla, 671 F.3d 1036, 1045 (9th Cir. 2012); see 8 U.S.C. 1229a(b)(1)(2); see also U.S. ConsT. amend. VI.

19. 8 U.S.C. $\S 1229 a(a)(1)(2012)$.

20. In fiscal year 2016, the asylum office completed 94,048 requests for credible fear interviews. AsYlum Div. OF THE U.S. Citizenship \& IMMIGRATION Servs., Credible Fear Workload Report Summary: FY 2016 Total Caseload 1 (2016),

https://www.uscis.gov/sites/default/files/USCIS/Outreach/Upcoming \%20National\%20 Engagements/PED_CredibleFearReasonableFearStatisticsNationalityReport.pdf 
Even after establishing this initial threshold eligibility for asylum, asylum seekers who receive a positive credible fear determination must still file an application with the immigration court. ${ }^{21}$ If an asylum seeker fails to file for asylum within one year of her arrival, she is barred from asylum unless she can establish extraordinary or changed circumstances to excuse her untimely filing. ${ }^{22}$

This Article focuses on the second and third category of asylum seekers: those who are filing applications defensively in immigration court, either because they were apprehended within the United States or because they passed a credible fear interview ${ }^{23}$ and were placed in removal proceedings. ${ }^{24}$

Regardless of the way in which asylum seekers enter the United States or whether they are in affirmative or defensive proceedings, most asylum seekers are required to file for asylum within one year of their arrival. $^{25}$

\section{B. The Origins of the One-Year Bar to Asylum}

Our current asylum system in the United States was created when Congress passed the Refugee Act in $1980,{ }^{26}$ essentially formalizing our joining the 1967 Protocol to the Convention on the Status of Refugees,

[https://perma.cc/DS26-EPLC] (provided at the Quarterly Stakeholder Meeting on November 4, 2016). This is a vast increase from previous years. In 2009, for example, USCIS completed just 5,523 cases, but this number has been steadily rising with a huge leap between $2012(13,607)$ and $2013(36,454)$ and a total of 49,607 in the fiscal year 2014. See Asylum Div. of the U.S. Citizenship \& Immigration Servs., Credible FEAR WORKLOAD REPORT SUMMARY - FY 09-14, at 1 (Oct. 28, 2014), http://www.uscis.gov/sites/default/files/USCIS/Outreach/Upcoming \%20National\%20E ngagements/PED_Credible_Fear_and_Reasonable_Fear_FY14_Q4.pdf [https://perma.cc/N3PL-LGV5].

21. See 8 U.S.C. $\S 1225(\mathrm{~b})(1)(\mathrm{B})(\mathrm{ii})$.

22. 8 U.S.C. $\S 1158(a)(2)(D)(2012)$.

23. For an excellent overview of the expedited removal and credible fear process, see Dree K. Collopy, Crisis at the Border, Part II: Demonstrating a Credible Fear of Persecution or Torture, 16-04 IMMIGR. BRIEFINGS 1 (Apr. 2016).

24. Although this Article focuses on defensive, rather than affirmative claims, the Author would note that the one-year filing deadline as it currently operates at the affirmative level actually serves to contribute to the backlog in immigration court. The asylum office is forced to refer cases to immigration court based on a failure to meet the one-year deadline that it would otherwise grant. See Karen Musalo \& Marcelle Rice, Center for Gender \& Refugee Studies: The Implementation of the One-Year Bar to Asylum, 31 Hastings InT'L \& COMP. L. REV. 693, 714-15 (2008).

25. As discussed later, "unaccompanied minors" (other than those from contiguous countries) are exempted from the one-year bar by the William Wilberforce Trafficking Victims Protection Reauthorization Act of 2008, now codified at INA $\S$ 208(a)(2)(E), 8 U.S.C. $§ 1185(a)(2)(E)$.

26. Pub. L. No. 96-212, 94 Stat. 102. 
thirteen years earlier. ${ }^{27}$ It was not until 1996 that Congress created the one-year deadline to apply for asylum, requiring all asylum seekers to file an application within one year of their last arrival in the United States. ${ }^{28}$ The deadline was ostensibly created to deter fraudulent asylum filings-the concern was that individuals were filing asylum applications solely to receive work authorization ${ }^{29}$ or to delay their

27. United Nations Convention Relating to the Status of Refugees, July 28, 1951, 189 U.N.T.S. 137 (entered into force Apr. 22, 1954); Protocol Relating to the Status of Refugees, Jan. 31, 1967, 19 U.S.T. 6223, 606 U.N.T.S. 267 (entered into force Oct. 4, 1967). The United States ratified the 1967 Protocol in 1968, which incorporates most provisions of the original 1951 Convention. See United Nations High Comm'R for Refugees, State Parties to the 1951 Convention Relating to THE Status OF REFugEes AND THE 1967 PROTOCOL 4, http://www.unhcr.org/3b73b0d63.pdf [https://perma.cc/5V4X-7DTT] (last visited Aug. 26, 2016).

28. 8 U.S.C. $\S 1158(a)(2)(B)$ (2012) ("Subject to subparagraph (D), paragraph (1) shall not apply to an alien unless the alien demonstrates by clear and convincing evidence that the application has been filed within 1 year after the date of the alien's arrival in the United States.”). This was created as part of the Illegal Immigration Reform and Immigrant Responsibility Act (IIRIRA) and applies to all asylum seekers filing for asylum after April 1, 1998. Pub. L. No. 104-208, 110 Stat. 3009 (codified in various sections of 8 U.S.C.).

29. The creation of the one-year deadline shortly followed another important change made to asylum law by regulation. Under 8 C.F.R. $§ 208.7(a)(1)$ (2012), asylum seekers may not receive work authorization until their asylum application has been pending for 180 days. Indeed, the Immigration and Naturalization Service (INS) (now USCIS) opposed the enactment of the one-year filing deadline. See Leena Khandwala et al., The One-Year Bar: Denying Protection to Bona Fide Refugees, Contrary to Congressional Intent and Violative of International Law, IMMIGR. BRIEFINGS 4 (Aug. 2005) ("Significantly, the former INS itself strongly opposed the bar. The agency had recently overhauled its asylum procedures to revoke the automatic issuance of work authorization upon filing a non-frivolous asylum application, to allow faster adjudication of asylum applications, and to refer claims that did not appear meritorious to immigration courts for removal proceedings. Doris Meissner, thenCommissioner of the INS, explicitly noted that the filing deadline (which, at that time, was proposed to be 30 days) would 'frustrate and hamper [the agency's reform] efforts,' and was unnecessary in light of the agency's own efforts to crack down on fraudulent claims.") (internal citation omitted); Michele R. Pistone, Asylum Filing Deadlines: Unfair and Unnecessary, 10 GEO. IMmigr. L.J. 95, 102 (1996) (citing Doris Meisser, Comm'r of the INS, News Conferences on the Asylum Reform Effort (Jan. 4, 1996), in CQ TRANSCRIPTIONS, Jan. 6, 1996, at 1, 7 (formally FDCH Political Transcripts)).

Several other mechanisms exist to deter and combat fraud and abuse of the asylum system. See Human Rights First, The Asylum Filing Deadline: Denying Protection to the Persecuted and Undermining Governmental Efficiency 26-27 (2010), https://www.humanrightsfirst.org/wp-content/uploads/pdf/afd.pdf [https://perma.cc/GF4P-47NJ] (these mechanisms include applicants signing the asylum application under penalty of perjury, prosecution of fraudulent filers, preparers, and attorneys, layers of identity and security checks, FBI fingerprint and name analysis, forensic testing of documents, and assistance and support for asylum officers from the Office of Fraud Detection and National Security). 
removal from the United States. During Senate hearings discussing the enactment of the deadline, Senator Alan K. Simpson of Wyoming questioned the motivations driving asylum applications filed more than one year after arrival. He stated that noncitizens arrested by immigration authorities after being undocumented in the United States for " 2,3 years and . . . say, 'I am seeking asylum' because they know that these procedures are interminable." 30

In enacting the one-year deadline, Congress enumerated two exceptions to the bar to asylum protection: where the asylum applicant has demonstrated "to the satisfaction of the Attorney General" that (1) changed circumstances exist which materially affect the applicant's eligibility for asylum, or (2) extraordinary circumstances exist and relate to the delay in filing. ${ }^{31}$

Changed circumstances include a situation where an individual who was previously not in danger suddenly became at risk-commonly due to shifting dynamics in the country of origin, for example, a coup, or the sudden or escalated targeting of a specific group of people. A changed circumstance could also originate with the individual herselffor example a woman who had a child out of wedlock may face harmful repercussions at home, or someone who discovered she was HIVpositive may fear danger upon return. ${ }^{32}$

Regulations enumerate examples of extraordinary circumstances exceptions to the one-year deadline and include: serious illness, mental or physical disability, legal disability, death or serious illness of a legal representative or an immediate family member, and prior possession of legal status. ${ }^{33}$ The Asylum Division of USCIS provides additional examples of extraordinary circumstances in its training materials for asylum officers, including, but not limited to, "severe family or spousal

30. 142 Cong. ReC. S4468 (daily ed. May 1, 1996) (statement of Sen. Simpson). Critiques of the filing deadline and its purpose to deter fraud have included the fact that if an individual is "sophisticated enough to concoct a fraudulent application [they are also] more likely to be aware of the deadline and to file within the allowable period . . . ." Philip G. Schrag et al., Rejecting Refugees: Homeland Security's Administration of the One-Year Bar to Asylum, 52 WM. \& MARY L. REV. 651, 762 n.227 (2010).

31. INA $\S 208(d), 8$ U.S.C. $§ 1158(a)(2)(D)$ (2012); see also 8 C.F.R. $\S$ 208.4(a), (a)(5) (2016).

32. The regulations enumerate "changed circumstances" that may excuse a late filing for asylum, including changes in conditions in the applicant's country or nationality, changes in United States applicable law, changes in the applicant's personal circumstances, and an applicant who was previously included as a dependent on another's pending asylum application who lost that relationship through marriage, divorce, or death. See Dree K. Collopy, Aila's Asylum Primer: A Practical Guide to U.S. Asylum LAW AND PROCEDURe 189-90 (7th ed. 2015) (citing regulations and case law on changed circumstances).

33. 8 C.F.R. $§ 208.4(a)(5)$. 
opposition, extreme isolation within a refugee community, profound language barriers, or profound difficulties in cultural acclimatization." 34 Notably, the Asylum Division goes beyond the guidance provided by the regulations, but no such guidance is issued for immigration judges. As discussed below, immigration judges fail to properly adjudicate even some of the clearly enumerated extraordinary circumstances, resulting in the denial of protection to genuine asylum seekers based on the filing deadline. ${ }^{35}$

Although, at the time, Congress remained "committed to ensuring that those with legitimate claims are not returned to persecution," 36 over the years, critics of the one-year deadline have argued that it operates to do just that-return vulnerable asylum seekers in need of protection to the harm from which they fled. ${ }^{37}$ The immediately proceeding section examines these critiques and discusses the ways in which the one-year filing deadline operates to bar protection for genuine refugees. The fear that the one-year filing deadline would return legitimate asylum seekers to persecution because of "technical difficulties" is now playing out in new ways in light of the immigration court backlog, as discussed below in Parts III and IV of this Article. ${ }^{38}$ First, however, it is worth focusing on the ways in which this twentyyear-old law was already harming refugees, prior to the existence of an extreme backlog of cases in immigration court.

34. U.S. Citizenship \& Immigration Servis. - RAIO - Asylum Div., Asylum Officer Basic Training Course: One-Year Filing Deadline 20 (Mar. 23, 2009),

https://www.uscis.gov/sites/default/files/USCIS/Humanitarian/Refugees \%20\%26\%20A sylum/Asylum/AOBTC\%20Lesson\%20Plans/One-Year-Filing-Deadline-31aug10.pdf [https://perma.cc/R5AX-4NCW].

35. See Musalo \& Rice, supra note 24, at 703-07 (explaining that adjudicators ignore Post-traumatic Stress Disorder (PTSD) avoidance symptoms and "frequently ignore or reject evidence of . . . psychological disorders when considering exceptions to timely filing"); Id. at 708 (explaining that applicants with seriously ill immediate family members are denied asylum for failure to file within one year, despite the clear regulatory exception). Hatch).

36. 142 Cong. REC. S11, 840 (daily ed. Sept. 30, 1996) (statement of Sen.

37. See infra Section I.C.

38. 142 Cong. REC. S11, 840 (daily ed. Sept. 30, 1996) (statement of Sen. Hatch) (assuring the Senate that the list of exceptions to the one-year deadline was nonexhaustive, meaning that "legitimate claims of asylum [would not be] returned to persecution, particularly for technical difficulties"). For a detailed analysis of the rate of rejection of asylum applications based on the one-year bar, see Schrag et al., supra note 30 , at 753 (estimating that 15,792 asylum applications would have been granted in the eleven years after the one-year bar was enacted if there was no deadline, in addition to their family member derivatives). 


\section{Operation of the One-Year Deadline to Bar Protection for Genuine Refugees}

Following the enactment of the one-year bar, a significant number of asylum seekers missed the deadline to apply for asylum. One study found that thirty percent of asylum applicants who filed between September 1998 and June 2008 missed the deadline to apply. ${ }^{39}$

One particularly vulnerable group of asylum seekers-survivors of gender-based harm, including those subjected to, or fleeing, forced marriage, female genital cutting (FGC), rape, and domestic violenceare frequently denied asylum based on their failure to meet the one-year deadline. ${ }^{40}$ It is clear, however, that these survivors and asylum seekers present legitimate asylum claims. In several cases, while immigration judges denied asylum, based solely on the failure to meet the one-year deadline, the very same judges also often found that these applicants met the heightened standard ${ }^{41}$ for withholding of removal, a lesser form of protection that has no deadline. ${ }^{42}$ A 2010 study analyzing more than 300,000 asylum cases filed with the Asylum Office between September 1998 and June 2009 revealed that women asylum seekers miss the oneyear deadline at a rate thirteen percent higher than male asylum seekers. ${ }^{43}$ The authors hypothesize that this is because women are more likely to be survivors of sexual violence and reluctant to disclose those experiences to government officials and also less likely, given the

39. Schrag et al., supra note 30 , at 688 .

40. Musalo \& Rice, supra note 24, at 700-02 (citing numerous examples of survivors of gender-based harm denied asylum based on the filing deadline but granted withholding of removal or relief under the Convention Against Torture); HuMAN RIGHTS FIRST, supra note 29, at 32-33.

41. This heightened standard requires that an individual be found "more likely than not" to face a "threat to her life or freedom" if returned to her country of feared persecution, rather than the asylum standard, which requires a "well-founded fear" of persecution. See INS v. Cardoza-Fonseca, 480 U.S. 421, 430-31 (1987) (standing for two important points: first, holding that asylum claims are not held to the "more likely than not standard" and that "well-founded fear" is a lower threshold, and, second, citing scholar A. Grahl Madsen for the proposition that the "well-founded fear" standard could be as low as a one-in-ten chance of future persecution); INS v. Stevic, 467 U.S. 407, 430 (1984) (holding that the "clear probability of persecution" standard applies to withholding of removal).

42. Cardoza-Fonseca, 480 U.S. at 430-31; see also HEARTLAND AlliANCE ET al., The One-Year Asylum Deadline and the BIA: No Protection, No Process: AN ANAlysis of BoARD of ImMigRation APPEALs DeCisions 2005-2008, at 2 (2010), https://www.humanrightsfirst.org/wp-content/uploads/pdf/1YD-report-FULL.pdf [https://perma.cc/M8WY-8MPW] (evaluating how the BIA applies the one-year deadline by analyzing 3,742 cases-obtained through a FOIA request-decided during the month of January in the time range from 2005-2008, and finding that many cases are denied based on the one-year deadline alone and meet the higher burden of proof and standard for withholding protection).

43. Schrag et al., supra note 30 , at $652,702$. 
evolving nature of gender-based asylum, to understand that they are eligible for asylum. ${ }^{44}$

Similarly, individuals fleeing targeted persecution on account of their sexual orientation have been harmed by the one-year deadline. ${ }^{45}$ An individual who has fled persecution on account of social stigma surrounding her identity in her home country is often culturally conditioned to feel shame and embarrassment surrounding the characteristic for which she is targeted. ${ }^{46}$ Logically, then, she may be reticent to quickly come forward and affirmatively share her experience with American immigration authorities.

In general, survivors of trauma and torture may also be negatively affected by the one-year filing deadline, as certain mental health conditions can affect an individual's ability to timely file for asylum. ${ }^{47}$ One of the hallmark symptoms of post-traumatic stress disorder (PTSD), for example, is avoidance. With avoidance, an individual may find it extremely difficult to talk about, think about, or explain the traumatic events she has endured. ${ }^{48}$ Despite this-and often despite

44. Id. at 702-03.

45. Victoria Neilson \& Aaron Morris, The Gay Bar: The Effect of the OneYear Filing Deadline on Lesbian, Gay, Bisexual, Transgender, and HIV-Positive Foreign Nationals Seeking Asylum or Withholding of Removal, 8 N.Y.C. L. REV. 233, 234 (2005); see also HumAn Rights FiRst, supra note 29, at 32-33; Musalo \& Rice, supra note, 24 at 701 (discussing the case of a Russian lesbian whose asylum claim was denied because of the deadline whose withholding removal was granted); Schrag et al., supra note 30, at 678-79 (sharing case of a gay Peruvian man denied asylum because of his delay in filing his application).

46. See HumAn Rights FiRst, supra note 29, at 32 (discussing the risk of further persecution when nature of mistreatment becomes public knowledge).

47. Stuart L. Lustig, Symptoms of Trauma Among Political Asylum Applicants: Don't Be Fooled, 31 Hastings InT'L \& Comp. L. Rev. 725, 731 (2008) (explaining how the avoidance symptoms of PTSD may inhibit an asylum seeker from timely submitting her application for asylum); see also HUMAN RIGHTS FIRST, supra note 29, at 29-32 (noting several examples of asylum seekers unable to file due to the mental health consequences of the trauma they had endured); Michele R. Pistone, Asylum Filing Deadlines: Unfair and Unnecessary, 10 GEO. IMMIGR. L.J. 95, 98-99 (1996) (writing before the enactment of the one-year deadline and explaining that trauma survivors need time to recover from traumatic events prior to filing an asylum application).

48. Post-Traumatic Stress Disorder (PTSD): Symptoms, Mayo CliniC (Apr. 15, 2014), http://www.mayoclinic.org/diseases-conditions/post-traumatic-stressdisorder/basics/symptoms/con-20022540 [https://perma.cc/9QRX-Z3VB]) (explaining that avoidance symptoms can include "[t]rying to avoid thinking or talking about the traumatic event; Avoiding places, activities or people that remind you of the traumatic event"); PTSD: National Center for PTSD, U.S. DEP'T. OF VETERANS AFFAIRS, http://www.ptsd.va.gov/public/PTSD-overview/basics/what-is-ptsd.asp

[https://perma.cc/S6ZU-JAB9] (last visited Aug. 26, 2016) (sharing the four types of symptoms of PTSD, including avoidance symptoms, described as "[a]voiding situations that remind you of the [traumatic] event. You may try to avoid situations or people that 
expert evidence and testimony-adjudicators misunderstand how these symptoms interfere with an ability to file, conflating general functionality in life of the applicant with her ability to undertake the necessary steps to file for asylum and disclose details of what is often deeply personal and deeply traumatic violence. ${ }^{49}$

Further, although status as an unaccompanied minor is specifically enumerated as an exception to the one-year deadline, ${ }^{50}$ (exceptions are discussed in further depth below) apparently some adjudicators have applied the bar to deny claims by unaccompanied minors. ${ }^{51}$ This is especially troubling as younger asylum seekers generally miss the deadline to apply at a higher rate than older asylum seekers, ${ }^{52}$ and the number of children seeking asylum has dramatically increased in recent years. ${ }^{53}$

trigger memories of the traumatic event. You may even avoid talking or thinking about the event.").

49. See HumAn Rights First, supra note 29, at 30 ("Even though individuals who are suffering from PTSD or other psychological disorders should be afforded exceptions to the filing deadline, many still find their cases denied or delayed as a result of the filing deadline. In some cases, adjudicators point to an applicant's ability to perform other tasks in their lives - such as maintain a job, take care of his or her children, or attend church - to conclude that the applicant had the capacity to file for asylum. This analysis reflects a fundamental misunderstanding about the nature of trauma and PTSD."); Khandwala et al., supra note 29, at 8 (explaining how immigration judges routinely find asylum to be barred for individuals living with PTSD who miss the deadline); see also Musalo \& Rice, supra note 24, at 703 ("An IJ who accepts that an applicant is suffering from a psychological disorder, but rejects the causal connection between the disorder and the delay in filing fails to recognize the phenomenon of avoidance symptoms. Some adjudicators conclude that if PTSD did not prevent an applicant from worshiping, giving birth, marrying, working, or studying in her first year after arrival, then it cannot have delayed the application for asylum.").

50. 8 C.F.R. $§ 208.4(a)(5)(i i)$ (2016) ("Legal disability (e.g., the applicant was an unaccompanied minor or suffered from a mental impairment) during the 1-year period after arrival") (emphasis added).

51. Musalo \& Rice, supra note 24, at 707-08 (reporting that "adjudicators apply the one-year bar to preclude claims presented by unaccompanied minors" and discussing the BIA decision, In re $Y$-C-, 23 I. \& N. Dec. 286 (B.I.A. 2002), which refused to create a per se exception for minors and interpreting the regulations to provide only a "possible" extraordinary circumstance for minors).

52. Schrag et al., supra note 30, at 706 (reporting that thirty-two percent of applications filed by zero-to-seventeen year olds were untimely filed and thirty-four percent of applications filed by eighteen-to-twenty-nine year olds were also untimely filed, in contrast to lower percentages for the older asylum seekers).

53. See Elizabeth Kennedy, No Childhood Here: Why Central AMERICAN CHILDREN ARE FleEING THEIR HOMES (July 2014), https://www.americanimmigrationcouncil.org/research/no-childhood-here-why-centralamerican-children-are-fleeing-their-homes [https://perma.cc/CMH9-44H9]; UNITED Nations High Comm'r for Refugees, Children on the Run: UnaCcompanied Children Leaving Central America and Mexico and the NeEd For INTERNATIONAL PROTECTION (Mar. 30, 2016), http://www.unhcr.org/en-us/aboutus/background/56fc266f4/children-on-the-run-full- 
Some asylum seekers simply do not know about the process for applying for asylum: language barriers, isolation, and other factors can make it difficult for them to discover their responsibility to file within one year of arrival in the United States. ${ }^{54}$ American immigration authorities make no affirmative efforts to advise or inform asylum seekers of the one-year deadline, even in instances where it is abundantly clear that the individual intends to apply for asylum, such as passing a credible fear interview. ${ }^{55}$ Despite the lack of notice and lack of general awareness among asylum seekers regarding the existence of the one-year deadline, courts have repeatedly found that "ignorance of the law is no excuse" for failing to comply with the one-year deadline. ${ }^{56}$ Other asylum seekers $d o$ timely submit their applications for asylum but fail to meet their legal burden of proof to establish, by clear and convincing evidence, that they had timely filed. ${ }^{57}$ Even in cases where the adjudicator finds the asylum seeker credible and to otherwise meet the standard for asylum, relief is denied. ${ }^{58}$

Finally, scholars have argued that the one-year deadline results in violations of the United States' international legal obligations under the 1967 Protocol to the Convention on the Status of Refugees. ${ }^{59}$ The

report.html?query $=$ children\%20on\%20the\%20run [https://perma.cc/BXG6-PHRV]; see generally Lauren A. Aronson, The Tipping Point: The Failure of Form Over Substance in Addressing the Needs of Unaccompanied Immigrant Children, 18 HARV. LATINO L. REV. 1 (2015).

54. HUMAN Rights FiRST, supra note 29, at 35-36.

55. See Mendez Rojas v. Johnson, No. 2:16-cv-01024-RSM (W.D. Wash. filed June 30,2016 ) (claiming that this lack of notice of the one-year deadline to asylum seekers violates not only the Immigration and Nationality Act, but also basic notions of due process and fairness under the Fifth Amendment).

56. Tian v. Holder, 745 F.3d 822, 824-26 (7th Cir. 2014) (finding no jurisdiction to review immigration judge and BIA determination that ignorance of the law does not constitute an extraordinary circumstance exception for missing the oneyear deadline); Uluiviti v. Holder, 509 F. App'x 629 (9th Cir. 2013) (citing AntonioMartinez v. INS, 317 F.3d 1089, 1093 (9th Cir. 2003) (stating the general proposition that ignorance of the law is no excuse)); Diego-Pedtro v. U.S. Att'y Gen., 324 F. App'x 791, 792-93 (11th Cir. 2009) (finding that ignorance of the law not to be an excuse for untimely filing and the court lacked jurisdiction to review this finding); Rashad v. Mukasey, 554 F.3d 1, 2-3 (1st Cir. 2009) (finding that ignorance of the law no excuse for untimely filing and the court lacked jurisdiction to review this finding); Rusu v. Mukasey, 298 F. App'x 588, 589 (9th Cir. 2008) (citing Antonio-Martinez, 317 F.3d at 1093); Mlambo v. U.S. Att'y Gen., 297 F. App'x 198, 200 n.3 (3d Cir. 2008) (immigration judge noting that ignorance of the law is no excuse to untimely filing and the BIA and court agreed).

57. HuMAN Rights FIRST, supra note 29, at 11.

58. Id.

59. Musalo \& Rice, supra note 24, at 722 ("The one-year bar has no impact on fraudulent claims. It does, however, cause the refoulement of legitimate refugees, in violation of international obligations.") (emphasis omitted); Nielsen \& Morris, supra note 45, at 278 ("Worse yet, those saddled with withholding are the 'lucky' ones. 
United Nations High Commission for Refugees has similarly expressed concern that the one-year deadline violates the United States' international refugee law obligations. ${ }^{60}$

Since its inception, scholars and immigrant advocates have critiqued the one-year bar for its failure to protect the groups discussed above as well as the way in which it undermines efficient adjudication of asylum claims. ${ }^{61}$ The interplay between the immigration court backlog, then, is just the latest iteration of how the filing deadline undermines the ability of asylum seekers to access protection in the United States.

\section{Why Withholding of Removal and Relief Under the Convention Against Torture are Inadequate}

Where an asylum seeker is barred from asylum by her failure to meet the filing deadline, an immigration judge considers her eligibility

There may be many thousands of deserving foreign nationals who were returned to the countries from which they fled even though they could have established a 'well-founded fear' of future persecution, but who were unable to meet the heightened 'more likely than not' probability of future persecution which is required for a grant of withholding."); Jaya Ramji, Legislating Away International Law: The Refugee Provisions of the Illegal Immigration Reform and Immigrant Responsibility Act, 37 STAN. J. INT'L L. 117, 141-42 (2001) ("While the INS is making efforts to minimize the impacts of the one-year deadline, the existence of such a strict time limit violates the duty of non-refoulement. . . . The deadline means that refugees are at risk of being returned to the country in which they fear persecution simply because they were unable to fulfill a formal, mechanistic requirement.") (emphasis omitted); Misha Seay, Better Late Than Never: A Critique of the United States' Asylum Filing Deadline from International and Comparative Law Perspectives, 34 Hastings INT'L \& COMP. L. ReV. 407, 426-27 (2011) (arguing that because genuine refugees may miss the one-year deadline, yet be unable to meet the higher standard for withholding of removal, they may be refouled in violation of United States treaty obligations under the Convention against Torture and the Protocol).

60. At a March 2010 event marking the 30th anniversary of the United States' Refugee Act of 1980, António Guterres, current UN Secretary General and then-United Nations High Commissioner for Refugees, described the one-year deadline as "diverg[ing] from international standards" and that it makes it "more difficult for many asylum seekers to establish their need for protection." António Guterres, United Nations High Comm'r for Refugees, Closing Keynote at Georgetown Law School Conference: 30th Anniversary of the Refugee Act of 1980 (Mar. 16, 2010); see also United Nations Gen. Assembly, Exec. Comm. of the High Comm'rs Programme, Note on International Protection, A/AC.96/898 (July 3, 1998) (noting that the "imposition of unreasonable time limits for the filing of asylum requests" could lead to refoulement of refugees).

61. Human Rights FIRST, supra note 29, at 2 (explaining that the one-year deadline delays the adjudication of cases referred to immigration court by the asylum office based on the deadline, as well as diverting time and resources by all adjudicators to "litigating a technicality, when those resources could instead be allocated to evaluating the actual merits of asylum cases, or could simply be saved or re-allocated to other matters"). 
for withholding of removal ("withholding") or relief under the Convention Against Torture (CAT) ${ }^{62}$ No filing deadline exists for either of those forms of protection. ${ }^{63}$ The legal elements to establish a claim for asylum and withholding of removal are the same-the asylum seeker must meet the legal definition of a refugee. ${ }^{64}$ But, withholding grantees must meet a heightened burden of proof, in terms of the likelihood of the future harm occurring, to be granted withholding. ${ }^{65}$ While an asylum seeker must show that she has a well-founded fear of persecution, which has been construed as low as a one-in-ten chance of future harm, ${ }^{66}$ to be granted withholding the applicant must prove that it is "more likely than not," of more than fifty percent likely, that she will face a threat to her life or freedom. ${ }^{67}$ Thus, an individual asylum seeker may be able to prove their burden of a ten percent chance of harm, but if she failed to file her application within one year, she may struggle to prove that it is fifty-one percent (or more) likely that she will be harmed in order to meet the heightened standard for withholding protection. ${ }^{68}$ Similarly, to be granted protection under CAT, the applicant must show that it is more likely than not, more than fifty-one percent likely, that she will be tortured if returned to her home country. ${ }^{69}$

Despite the higher burden of proof for withholding protection, it is indisputably a lesser form of relief. The ways in which withholding and CAT relief are inferior forms of relief to asylum are discussed below, but where an individual is barred from asylum by the one-year deadline, this is the only relief available.

First, an asylum seeker is able to adjust status after one year of physical presence in the United States and become a lawful permanent resident,${ }^{70}$ and eventually a citizen. The same is not true for individuals

62. 8 C.F.R. $§ 208.18$ (b)(1), (b)(3) (2016).

63. HUMAN Rights FirSt, supra note 29, at 7.

64. See INA $\S 101(a)(42)(A), 8$ U.S.C. $\S 1101$ (a)(42)(A)-(B) (2012).

65. HUMAN Rights First, supra note 29, at 9.

66. INS v. Cardoza-Fonseca, 480 U.S. 421, 431 (1987).

67. INS v. Stevic, 467 U.S. 407, 429-30 (1984).

68. This problem may be ameliorated by a regulatory presumption that those demonstrating "past persecution" meet the higher standard for withholding of removal. 8 C.F.R. $\S 1208.16$ (b)(1)(i) (2016). Not all asylum seekers who have a well-founded fear of future persecution will be able, however, to establish that they have suffered past persecution in order to benefit from this presumption for both asylum and withholding relief.

69. 8 C.F.R. $\$ \S 208.16(c)(2), 1208.16(c)(2)$ (2016). Unlike withholding of removal under the INA, there is no regulatory presumption of future torture arising from proof of past torture, although past torture is a factor that should be considered in establishing the probability of future torture. See Id. $\S 1208.16(\mathrm{c})(3)(\mathrm{i})$.

70. See INA § 209(b), 8 U.S.C. § 1159(b)(2) (2012). 
granted withholding or CAT. ${ }^{71} \mathrm{CAT}$ grantees receive an order prohibiting their return to the country where they fear torture, but says they could be transported elsewhere. ${ }^{72}$ These individuals, often survivors of torture and trauma, are left in limbo, constantly in fear of being returned to their home country or to another country (if the United States government can secure this transfer). Further, withholding grantees receive a removal order and, usually, must check in periodically with Immigration and Customs Enforcement (ICE) officials-which require lengthy waits in ICE offices on a weekly, monthly, or somewhat less frequent basis. ${ }^{73}$ Finally, while withholding grantees are eligible for work authorization, their work permit is valid for just one year and they must apply each year to renew their authorization for employment. ${ }^{74}$

Second, an asylee may file a petition for her spouse and unmarried children under the age of twenty-one at the time she files for asylum. ${ }^{75}$ While this process of family reunification is often delayed and lengthy, ${ }^{76}$ eventually, the family may be reunited. A failure to reunite family members who remain overseas, often in danger, has been shown to have detrimental mental health effects for the asylee. ${ }^{77}$ In contrast, withholding recipients do not have the right to petition to reunite with their family members overseas.

Third, an asylee may apply for a refugee travel document and receive permission to travel outside the United States. ${ }^{78}$ A withholding recipient, however, is unable to travel, at least if she intends to return to the United States, ${ }^{79}$ which undermines not only familial relationships

\footnotetext{
71. HuMAN Rights FirSt, supra note 29, at 9.

72. Id.

73. Id. at 20 .

74. An initial employment authorization card granted to an asylee, in contrast, is valid for two years. It may be renewed annually but asylees may also adjust status to permanent residents after one year, after which time a work permit is no longer necessary. Asylees also are not technically required to have a work permit in order to work, see OfFICE OF SPECIAL COUNSEl FOR IMMIGRATION-RELATED Unfair EmP'T PRACTICES, Refugees AND Asylums Have the Right to Work, http://www.justice.gov/crt/about/osc/pdf/refugee_asyleeflyer32510.pdf [https://perma.cc/7WY5-T84G] (last visited Aug. 26, 2016), but many choose to do so as a form of identification and because many employers expect documentation of this nature.

75. See INA $\S 208(b)(3)(A)-(B), 8$ U.S.C. $\S 1158(b)(3)(A)-(B)(2012)$.

76. See Lindsay M. Harris, From Surviving to Thriving? An Investigation of
} Asylee Integration in the United States, 40 N.Y.U. REV. L. \& Soc. ChAnge, 29, 46, 55,119 (2016) (providing a comprehensive guide to the benefits and services to which asylees are entitled).

77. HUMAN Rights FiRST, supra note 29, at 20-23.

78. 8 C.F.R. $\S \S 223.1,223.2$ (a) (2016).

79. Neilson \& Morris, supra note 45, at 247. 
with those outside the country, but also potentially employment opportunities for individuals who may possess desirable language skills. ${ }^{80}$

Fourth, asylees are eligible for various benefits and services offered through the Office of Refugee Resettlement. ${ }^{81}$ In contrast, withholding and CAT recipients are eligible for a more limited set of benefits and services. ${ }^{82}$

These differences are stark. The one-year filing deadline draws a harsh line between the individuals who meet that deadline and those who do not. All applicants for asylum also automatically apply for withholding relief and relief under CAT ${ }^{83}$ If an asylum seeker misses the one-year deadline, she will only be considered for the latter two forms of relief. ${ }^{84}$ Unless an asylum seeker who misses the deadline can convince a judge that she meets an exception, she will be denied asylum. ${ }^{85}$ Next, unless that asylum seeker convinces the judge that she meets the higher burden for protection in the form of withholding or CAT relief, she will be deported to a place where she faces anywhere from a ten-to-fifty percent chance of persecution. ${ }^{86}$ Even if she can convince the judge that she meets the higher standard, if granted withholding or CAT protection, she will: (1) never become a permanent resident or citizen; (2) live in fear of deportation should the United States decide to remove her to a third country; (3) likely never see her overseas children or spouse again; (4) generally not receive any services or benefits to assist in her integration to the United States, even if she is destitute and living far below the poverty line; and (5) never be able to travel outside the United States for personal, family, or employment purposes. ${ }^{87}$ Individuals granted withholding or CAT relief are living in a legal purgatory-unable to truly integrate and become members of our society, despite their living, working, and raising

80. HUMAN Rights FIRST, supra note 29, at 21 (recounting the case of an Egyptian asylum seeker granted withholding protection unable to accept a job overseas as an Arabic interpreter with the United States military in Iraq).

81. Harris, supra note 76, at 40-42, 44-47, 119-24 (Appendix B details the benefits and services for which asylees may be eligible).

82. HumAn Rights FIRST, supra note 29, at 20-22 (explaining that withholding recipients are at risk of deportation, are separated from their families, cannot apply for permanent resident states, have difficulties obtaining an education, and difficulty obtaining employment).

83. 8 C.F.R. $§ 208.3(a),(b)(2016)$.

84. Id. $\S 208.4(\mathrm{a})(2)(\mathrm{A})$.

85. Id. $§ 208.4(\mathrm{a})(5)$.

86. HumAn Rights FIRST, supra note 29, at 9; INS v. Cardoza-Fonseca, 480 U.S. 421, 431, 440 (1987).

87. Neilson \& Morris, supra note 45, at 246-48, 250-51; HUMAN RigHTS FIRST, supra note 29, at 9, 20-22. 
families in the United States. ${ }^{88}$ Unfortunately, despite the recent policy change announced by EOIR, pro se asylum seekers remain especially at risk of missing the one-year deadline. ${ }^{89}$ These unrepresented individuals may not be granted the protection they deserve due to the effects of the immigration court backlog, a lack of notice of the one-year deadline, and a shortage of competent, affordable or pro bono, legal representation, discussed below.

\section{IMMIGRATION COURT BACKLOG \& A CRISIS OF REPRESENTATION}

\section{A. The Extreme Immigration Court Backlog}

The EOIR currently has fifty-seven immigration courts and approximately 291 immigration judges. ${ }^{90}$ For years, researchers have warned of a coming crisis and of the difficult professional atmosphere in which immigration judges must work, with inadequate support staff and overwhelming dockets, which are generally beyond the control of local judges. ${ }^{91}$ Under these sparse conditions, immigration judges adjudicate, as immigration judge Dana Leigh Marks has famously explained, "death penalty cases" in "traffic court." 92

88. HumAn Rights FIRST, supra note 29, at 2 (reporting that the depriving refugees of the ability to become permanent residents and United States citizens "[u]ndercut[s] governmental interests in integration" and also makes it "more difficult for them to access jobs and education"); see also Nielsen \& Morris, supra note 45, at 278, 280 ("[T]he implementation of the one-year deadline has created a new, and perhaps unexpected, class of individuals who are forever trapped in the United States in the limbo status of withholding of removal. . . . The failure to comply with a procedural deadline is no justification for holding human lives in a permanent state of limbo-a state of limbo which is produced by prohibiting those with withholding status from ever traveling outside the United States or petitioning for relatives to join them here. These prohibitions leave those granted withholding unable to ever fully become a part of American society.").

89. Memorandum from Michael C. McGoings, supra note 7.

90. See Press Release, Exec. Office for Immigration Review, supra note 2.

91. Stuart L. Lustig et al., Inside the Judges' Chambers: Narrative Responses from the National Association of Immigration Judges Stress and Burnout Survey, 23 Geo. ImmigR. L.J. 57 (2008); Betsy Cavendish \& Steven Schulman, Reimagining the Immigration Court Assembly Line: Transformative Change FOR the IMMIGRATION JUSTICE SYSTEM (2012), http://www.appleseednetwork.org/wpcontent/uploads/2012/03/Reimagining-the-Immigration-Court-Assembly-Line.pdf [https://perma.cc/53DE-P977].

92. Executive Office for Immigration Review: Hearing Before the Subcomm. on Immigration, Citizenship, Refugees, Border Sec., \& Int'l Law of the Comm. on the Judiciary H.R., 111th Cong. 55 (2010) (written statement of Hon. Dana Leigh Marks, President, National Association of Immigration Judges) ("Currently, complex and highstakes matters, such as asylum cases that can be tantamount to death penalty cases, are being adjudicated in a setting that most closely resembles traffißc court."). 
In recent years, increasing caseloads have begun to overwhelm courts and judges. The backlog of cases yet to be heard across the nation is currently over $521,000 .{ }^{93}$ This backlog results in a dramatic wait time, simply for the first scheduling hearing before an immigration judge - known as the master calendar hearing - of an average of 675 days, or close to two years. ${ }^{94}$ At the master calendar hearing, the immigration judge issues certain advisals, counsel may enter an appearance, pleadings may be taken, and a merits or "individual" hearing will be scheduled. ${ }^{95}$ Applications for relief from removal may be filed at the initial or a subsequent master calendar hearing. ${ }^{96}$ It is not until the individual merits hearing that an asylum seeker's application for asylum will be adjudicated-following the presentation of evidence, testimony, and witnesses. ${ }^{97}$ Only after this individual hearing, which may be scheduled anywhere from two-to-six years into the future, can an immigration judge render a decision on the merits of the asylum claim. ${ }^{98}$ Experts estimate that if current staffing levels of judges and administrators at immigration courts persist, the backlog will reach one million by $2022 .^{99}$

The immigration court backlog undoubtedly poses problems and challenges for many immigrants, ${ }^{100}$ who endure years of uncertainty,

93. See Caldwell, supra note 2; see also Backlog of Pending Cases in Immigration Court as of September 2016, supra note 2.

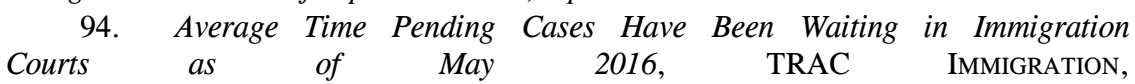
http://trac.syr.edu/phptools/immigration/court_backlog/apprep_backlog_avgdays.php [https://perma.cc/7VHD-P3E5] (reflecting an average of 675 days for adjudication of immigration court cases nationwide). It is important to note that the TRAC numbers only reflect the average time that individuals have already been waiting for adjudication of their claims and not the total time that they will in fact wait for adjudication. In September 2015, TRAC estimated that actual full adjudication of cases in the backlog would take between 659 and 2,401 days. See Ballooning Wait Times for Hearing Dates in Overworked Immigration Courts, TRAC IMMIGRATION (Sept. 21, 2016), http://trac.syr.edu/immigration/reports/405/ [https://perma.cc/A2SE-U7FA].

95. Immigration Court Practice Manual $\S 4.15$ (U.S. DeP’t of Justice 2016).

96. Id. $\S 4.15(\mathrm{i})(\mathrm{i})$.

97. $\quad$ See generally id. $§ 4.16$.

98. An immigration judge may render an oral or written decision after an individual merits hearing. Id. $\S 4.16(\mathrm{~g})$.

99. Human Rights First, In the Balance: Backlogs Delay Protection in THE U.S. ASYlum AND IMMigRATION COURT SySTEMS ii (2016), http://www.humanrightsfirst.org/sites/default/files/HRF-In-The-Balance.pdf [https://perma.cc/4PCE-KE49] (estimating that the case backlog would reach over 500,000 by the end of Fiscal Year 2016 and one-million by 2022).

100. See generally HUMAN RIGHTS FIRST, supra note 99 (discussing mental health issues posed by the delay in adjudication, along with problems with integration into the workforce and the harmful effects of prolonged separation from family members, many of whom are living overseas in danger); see also Empty Benches: 
waiting for their day in court, and for justice to be administered in their cases. As Human Rights First has reported, the backlog results in delays approaching five years in some parts of the country:

As a result of the ballooning backlogs at the immigration courts, hundreds of thousands of immigrants are in a state of legal limbo for more than three years on average. The most delayed courts have wait times of four to five years. For example, it will take the Newark court more than five years to hear currently pending cases. In Texas, immigrants and asylum seekers must now wait on average over 1,700 days-nearly five years-for their cases to be resolved. In Maryland they wait nearly two years, in Georgia and Alabama three and a half years, in Arizona more than three years, and in California nearly three years. Since 2014 alone, wait times have grown by 34 percent in Houston, 28 percent in Dallas, 20 percent in Newark, and 15 percent in Baltimore. Immigrants in New York can expect to wait at least two and a half years for the court to consider their case. ${ }^{101}$

These backlogs have an especially deleterious effect on asylum seekers, however, due to the dysfunctional mechanics of the one-year deadline. ${ }^{102}$ By regulation, an asylum application is "filed" for the purposes of meeting the one-year filing deadline if it is "received by" an immigration court or the Board of Immigration Appeals. ${ }^{103}$ Similarly, nothing in the Immigration and Nationality Act specifies how an asylum application should be filed. ${ }^{104}$ It appears then, according to the statute and the regulations, that all an asylum applicant must do to file her application is to ensure that the immigration court physically receives her application before the deadline.

Underfunding of Immigration Courts Undermines Justice, AMERICAN

IMMIGRATION COUNCIL (June 17, 2016),
https://www.americanimmigrationcouncil.org/sites/default/files/research/empty_benche s_underfunding_of_immigration_courts_undermines_justice.pdf

[https://perma.cc/5EQ7-YURW] (explaining that long delays caused those eventually granted relief to suffer, cause family separation, undermine ability to work and contribute financially, along with prolonged detention of individuals).

101. HumAn Rights FirST, supra note 99, at 6.

102. Other adverse ramifications of the immigration court and affirmative asylum backlog on asylum seekers include prolonged family separation, potentially leaving children and spouses in danger overseas, deleterious mental health effects, delays to integration through education and employment, and undermining of pro bono representation. See Human Rights FIRST, supra note 99, at iii.

103. 8 C.F.R. $\$ 208.4($ a)(2)(B)(ii) (2016).

104. See generally INA $\S \S 101-507,8$ U.S.C. $\S \S 1101-537$ (2012). 
Yet until very recently, this straightforward procedure-simply filing an application with the court-was not accepted according to agency practice. ${ }^{105} \mathrm{~A}$ memo from the Chief Immigration Judge in March 2000 made it clear that defensive asylum applications should be filed in open court. ${ }^{106}$ The open-court filing requirement was later adopted by EOIR's immigration court practice manual, first issued in 2008, which made clear that asylum applications are filed in open court at a master calendar hearing presided over by an immigration judge. ${ }^{107}$

EOIR never explained the rationale behind the in-court filing requirement, ${ }^{108}$ but on September 14, 2016, announced a policy change to permit asylum applications to be filed, for one-year bar purposes, at the court window, rather than in open court. ${ }^{109}$ This step forward is important because master calendar hearings, at which an individual could file their asylum application, are frequently scheduled beyond one year after an individual asylum seeker's entry into the United States. ${ }^{110}$

105. 8 C.F.R. $\S 208.4(a)(2)(B)(i i)$.

106. Michael J. Creppy, Chief Immigration Judge, Operating Procedures and Policy Memorandum 00-01, Asylum Request Processing (Aug. 4, 2000) ("Local Court rules notwithstanding, including any such rules related to the filing of Motions for a Change of Venue, defensive asylum applications can only be filed with the Immigration Court at a Master Calendar or a Master Calendar Reset Hearing. This is true even where the defensive asylum application is filed in conjunction with other applications for relief. However, the Chief Immigration Judge may, from time to time as circumstances require, expressly permit an exception to this general rule") (emphasis changed from underlining to italics.).

107. Immigration Court Practice Manual $\S 3.1$ (b)(iii) (U.S. Dep't of JUSTICE 2016) (“A defensive asylum applications are filed in open court at a master calendar hearing."). It is worth noting that other sections of the practice manual use language such as "should" or "must" and so potentially there is an argument that the softer language of this provision always enabled judges to accept asylum applications lodged at the court window as "filed." The concept of lodging versus filing is discussed below in subsection II.B., infra note 128.

108. A closer examination of the statute may shed light on the reason for the apparent open-court filing requirement, which EOIR never explained. INA § 208(c)(4) states that "at the time of filing an application for asylum," the immigration judge (through power delegated from the Attorney General) shall advise the applicant of the privilege of representation along with the warning regarding making a frivolous application for asylum. INA $\S 208(c)(6), 8$ U.S.C $\S 1158(d)(4)(2012)$ states that "if the Attorney General determines that an alien has knowingly made a frivolous application for asylum and the alien has received the notice under paragraph 4(A), the alien shall be permanently ineligible for any benefits under this Act . . . ." Perhaps, then, the rationale for filing an asylum application in court was to enable a judge to render the oral advisals regarding filing a frivolous asylum application.

109. Immigration Court Practice Manual $\S 3.1(\mathrm{a})(\mathrm{v})$.

110. Motion for Class Certification at 5, Mendez Rojas v. Johnson, No. 2:16cv-01024-RSM (W.D. Wash. filed July 21, 2016) (explaining that many master calendar hearings are not scheduled until after the one-year deadline). Indeed, the master calendars are not scheduled just days, weeks, or months beyond the deadline. In working with the CARA Project and attorneys across the nation while at the American 
Thus, through no action or fault of her own-and only because of the tremendous backlog of removal cases and administrative scheduling of the court-prior to the September 14, 2016 policy change, an asylum seeker often completely lacked an opportunity to timely file her application in open court as directed by the immigration court practice manual. ${ }^{11}$

The recently announced policy change, explored in more detail in Part III below, does not entirely remedy the situation for all asylum seekers, and, in fact, creates a worse situation for pro se asylum seekers, as discussed in the next section.

\section{B. A Crisis in Legal Representation of Asylum Seekers}

Immigrants do not have a right to a government-appointed attorney in immigration proceedings, although they may hire one at their own expense or through pro bono services. ${ }^{12}$ Most immigrants, including the majority of asylum seekers, lack legal representation. ${ }^{113}$ Indeed, a national study of immigration cases from 2007-2012 found that only thirty-seven percent of all immigrants and only fourteen percent of detained immigrants secured legal representation in removal proceedings. ${ }^{114}$ That study also found that law school clinics, nonprofits, and pro bono law firm representation only account for two percent of that representation in removal proceedings. ${ }^{115}$

Of cases involving adults with children decided between July 2014 and September 2016, seventy percent of the families were

Immigration Council, exploring this issues in 2015-2016, the Author routinely heard of individuals being set for their first master calendar hearing in late 2019, three or four years after their last arrival into the United States.

111. Aside from the simple fact of the immigration court backlog itself, causing many master calendar hearings to be scheduled beyond the one-year deadline for a particular asylum applicant, there are other delays in the system. As the Mendez Rojas complaint explains, "[f]irst, DHS agents often issue a charging document . . . and serve it on the individual, but delay filing it with the immigration court-sometimes for months or even a year or longer." Complaint at 3, Mendez Rojas v. Johnson, No. 2:16cv-01024-RSM (W.D. Wash. filed June 30, 2016).

112. See INA $\S 240(b)(4)(A), 8$ U.S.C. $§ 1229 a(b)(4)(A)$ (2012) (stating that the "alien shall have the privilege of being represented, at no expense to the Government, by counsel of the alien's choosing who is authorized to practice in such proceedings"); 8 C.F.R. $§ 1003.16$ (b) (2016). The United States has a long history of denying Sixth Amendment rights to immigrants in removal proceedings. See Fong Yue Ting v. United States, 149 U.S. 698 (1893) (holding that three Chinese residents facing deportation were not entitled to criminal constitutional protections because they were being subjected to civil deportation proceedings).

113. Ingrid V. Eagly \& Steven Shafer, A National Study of Access to Counsel in Immigration Court, 164 U. PA. L. REV. 1, 2 (2015).

114. Id.

115. Id. at 27 . 
unrepresented. ${ }^{116}$ Of the unrepresented families, only one-in-fifteen managed to file an application for asylum pro se and forty-three percent were ordered deported at their initial master calendar hearing. ${ }^{117}$ The Obama Administration placed these women and children on a special priority docket, ${ }^{118}$ created in response to the humanitarian crisis and increasing numbers of individuals from Central America seeking protection in the United States, and can largely be presumed to be asylum seekers.

Many asylum seekers exhaust their financial resources in fleeing to the United States and, upon arrival, are unable to legally work until 180 days after their asylum application has been filed. ${ }^{119}$ Unfortunately, immigration law is one of the most complex areas of law and has been compared to the tax code in its labyrinthine nature. ${ }^{120}$ Navigating the procedural requirements, let alone the complex substantive law alone, is daunting to say the least. Indeed, a recent study on the effectiveness of legal representation found that lawyers may have the greatest impact where they help individuals navigate procedures that may be simple for attorneys, but are complex for pro se individuals. ${ }^{121}$

116. With the Immigration Court's Rocket Docket Many Unrepresented Families Quickly Ordered Deported, TRAC IMMIGRATION (Oct. 18, 2016), http://trac.syr.edu/immigration/reports/441/ [https://perma.cc/A3MZ-NUDC] $(27,015$ out of the 38,601 adult with children closed cases did not have legal representation, while legal representation was secured in only thirty percent, 11,586 cases).

117. Id.

118. In response to the President's efforts to expeditiously react to the humanitarian crisis (see Letter from the President--Efforts to Address the Humanitarian Situation in the Rio Grande Valley Area of Our Nation's Southwest Border, White House (June 30, 2014), https://www.whitehouse.gov/the-pressoffice/2014/06/30/letter-president-efforts-address-humanitarian-situation-rio-grande-

valle [https://perma.cc/8FFH-HKUC]), the Chief Immigration Judge set up priority dockets for unaccompanied children and for children detained with their parents (known as the "AWC"-Adults With Children-docket). See Memorandum from Judge Brian M. O'Leary, Chief Immigration, U.S. Dep't of Justice, on Docketing Practices Related to Unaccompanied Children in Light of the New Priorities, to all Immigration Judges (Sept. 10, 2014), https://www.justice.gov/sites/default/files/eoir/legacy/2014/09/30/Docketing-PracticesRelated-to-UACs-Sept2014.pdf [https://perma.cc/2SZ7-Z8WJ].

119. For a detailed discussion of the delayed right to work for asylum seekers, see Lori A. Nessel, Deliberate Destitution as Deterrent: Withholding the Right to Work and Undermining Asylum Protection, 52 SAn Diego L. REV. 313, 316 (2015).

120. Baltazar-Alcazar v. INS, 386 F.3d 940, 948 (9th Cir. 2004) ("With only a small degree of hyperbole, the immigration laws have been termed second only to the Internal Revenue Code in [its] complexity. A lawyer is often the only person who could thread the labyrinth," quoting Castro-O'Ryan v. U.S. Dep't of Immigration \& Naturalization, 847 F.2d 1307, 1312 (9th Cir. 1987)).

121. See Rebecca L. Sandefur, Elements of Professional Expertise: Understanding Relational and Substantive Expertise Through Lawyers' Impact, 80 АM. SOC. REV. 909, 924 (2015). 
Representation is particularly limited outside of major metropolitan areas and for detained individuals. ${ }^{122}$ Professor Michele Pistone's rather prescient article, written twenty years ago-prior to the enactment of the one-year deadline-outlined the advocacy community's fears at that time about a lack of pro bono representation and the time it takes for an asylum seeker to secure affordable or pro bono representation. ${ }^{123}$

Why does legal representation matter so much? Not only do qualified and competent attorneys help to raise awareness of and avoid complications caused by the one-year deadline, but also their overall effect on the outcome of the case is positive for immigrants. ${ }^{124}$

122. LORI A. NeSSEl \& FARrin ANEllo, Deportation Without RePresentation: The ACCESS-TO-Justice Crisis Facing NeW Jersey's IMmigrant FAMILIES 2-3 (2016) (finding that two-thirds of detained immigrants in New Jersey never had any representation throughout their removal proceedings and "New Jersey lacks sufficient capacity to meet the legal services needs of adults, children, and families in removal proceedings"); Eagly \& Shafer, supra note 113, at 41 ("Immigrants detained in small cities had the lowest representation rate-only $10 \%$ across all cities of fewer than 50,000 residents."); Jayashri Srikantiah et al., Access to Justice for Immigrant Families and Communities: A Study of Legal Representation of Detained Immigrants in Northern California, 11 StAN. J. CiV. RTS. \& Civ. Liberties 207, 220, 222 (2015) (finding that only one-third of detained immigrants were represented in removal proceedings in Northern California between March 1, 2013 and February 28, 2014); Steering Comm. of the N.Y. Immigrant Representation Study Report, Accessing Justice: The Availability and Adequacy of Counsel in Removal Proceedings, 33 CARdozo L. Rev. 357, 363 (2011) (reporting that in New York City, sixty percent of detained immigrants do not have counsel by the time their cases are completed); see generally Margaret H. Taylor, Promoting Legal Representation for Detained Aliens: Litigation and Administrative Reform, 29 CONN. L. REV. 1647 (1997). The number of detained asylum seekers has also increased in recent years. See Olga Bryne ET AL., LifELINE ON Lockdown: InCREASED U.S. DETENTION OF ASYLUM SEEKERS 2 (2016), http://www.humanrightsfirst.org/resource/lifeline-lockdown-increased-us-detentionasylum-seekers [https://perma.cc/Q2ML-MWHF] ("The number of asylum seekers sent to and held in immigration detention has increased nearly threefold from 2010 to 2014 . In FY 2010, 15,683 asylum seekers-or 45 percent of all asylum seekers in removal proceedings-were detained. In FY 2014, that number jumped to 44,228-77 percent of all asylum seekers in court proceedings.").

123. Michele R. Pistone, Asylum Filing Deadlines: Unfair and Unnecessary, 10 GeO. ImmigR. L.J. 95, 100-01 (1996); see also Schrag et al., supra note 30, at 757 (" $[R]$ esearch has demonstrated that asylum seekers face a multitude of barriers to securing representation.”).

124. See U.S. Gov't Accountability Office, U.S. Asylum System: Significant VAriation Existed in AsYlum Outcomes ACross IMmigration Courts AND JUDGES 7 (2008), http://www.gao.gov/new.items/d08940.pdf [https://perma.cc/ESH8-BAKH] ("Representation generally doubled the likelihood that immigration judges would grant asylum to affirmative and defensive asylum applicants compared to those without representation, after statistical controls were applied."); NESSEL \& ANELlO, supra note 122, at 15 (finding that only fourteen percent of pro se immigrants secured a successful outcome in their removal proceedings versus forty-nine percent with representation by an attorney); RAMJI-NOGALES ET AL., infra note 235, at 45 (Figure 3-11 illustrating the relationship between representation and grant rates in immigration court: sixteen percent of unrepresented individuals are granted asylum 
Prior to EOIR's September 14, 2016 policy change-allowing asylum applications to be filed at the court window, rather than solely in open court ${ }^{125}$-diligent and creative advocates executed a range of legal strategies in attempts to preserve asylum eligibility. ${ }^{126}$ In many cases, attorneys successfully preserved the one-year filing deadline by establishing an extraordinary circumstances exception (examples discussed below). Those prior practices included:

(1) filing a motion to advance the hearing date; ${ }^{127}$

versus a grant rate of nearly forty-six percent for those with representation); ANDREW I. SCHOENHOlTZ ET AL., Lives IN THE BALANCE: ASYlum AdJUdicATion BY THE DEPARTMENT OF HoMELAND SECURITY 133-42 (2014) (between October 1995 and June 2009, DHS granted asylum nineteen percent more often to represented asylum seekers than to pro se applicants); Eagly \& Shafer, supra note 113, at 2 ("Moreover, we find that immigrants with attorneys fared far better: among similarly situated removal respondents, the odds were fifteen times greater that immigrants with representation, as compared to those without, sought relief, and five-and-a-half times greater that they obtained relief from removal.”); Benson \& Wheeler, supra note 6, at 56 (ninety-two percent of immigration judges who responded to a survey question agreed with the following statement: "When the Respondent has a competent lawyer, I can conduct the adjudication more efficiently and quickly").

125. Immigration Court Practice Manual $\S 3.1(\mathrm{a})(\mathrm{v})$ (U.S. DeP’T of JUSTICE 2016).

126. These strategies are largely drawn from the practice advisory issued by the American Immigration Council in January 2016. While a Legal Fellow at the American Immigration Council, I co-authored the practice advisory, which recommends that practitioners adopt this four-pronged approach to demonstrate good faith efforts to file the asylum application in advance of one year in the absence of a court date. See Sandra A. Grossman \& Lindsay M. Harris, Preserving the OneYear Filing Deadline for CASES Stuck in the ImMigration Court BACKLOG, PRACTICE ADVISORY 6-8, 11 (2015), https://www.americanimmigrationcouncil.org/sites/default/files/practice_advisory/preser ving_the_one-year_filing_deadline_for_asylum_cases_stuck_in_the_immigration_

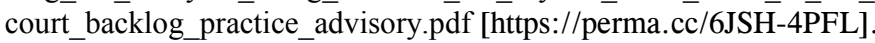

127. Id. at 6-8. Although the immigration court practice manual makes clear that a motion to advance is "disfavored," the manual also gives an example of where a hearing date may be advanced: "imminent ineligibility for relief, such as a minor alien 'aging out' of derivative status." IMMIGRATION COURT PRACTICE MANUAL $§ 5.10(\mathrm{~b})$. In the case where the deadline is approaching and the master calendar date-which would allow the individual to comply with the practice manual and file in open court-is scheduled beyond the deadline, the attorney could argue that their client, like an aging out derivative child, will face "imminent ineligibility" for relief if a master calendar hearing was not advanced to permit filing of the asylum application. While this seems simple enough, in operation filing the motion was often difficult because Notices to Appear (NTA) will often simply state that a date, time, and judge for the first master calendar hearing is "TBD"-to be decided, as was the case with Liana's NTA, discussed below.

In common immigration court practice, a motion should be directed to a particular judge and some courts do not know what to do with motions filed generally with the court. When a motion to advance was filed, it typically made a simple request that the judge advance the hearing date to permit timely filing of the I-589 application. GROSSMAN \& HARRIS, supra note 126, at 8. The responses to these motions were 
(2) "lodging" the application with the immigration court; ${ }^{128}$

(3) filing the application with the asylum office; ${ }^{129}$ and

mixed-some judges granted them, rescheduling the master calendar hearing and enabling timely filing. But, no statutory, regulatory, or other guidance exists requiring immigration judges to adjudicate motions on any specific timeline. So, other judges failed to review or respond to the motion before the deadline, while others denied the motions-sometimes making clear, orally or in writing, that they intended to construe the delay as an extraordinary circumstance or will accept "lodging" as filing, and at other times simply denying the motion with no indication of their intended decision on the issue of the deadline. This left attorneys and asylum seekers in limbo, and, in some cases, without a remedy for missing the deadline.

128. GROSSMAN \& HARRIS, supra note 126, at 6-7. Memorandum from Judge Brian M. O'Leary, Chief Immigration, U.S. Dep't of Justice, on Operating Policies and Procedures, to all Immigration Judges, Attachment B (Dec. 2, 2013), https://www.justice.gov/sites/default/files/eoir/legacy/2013/12/03/13-03.pdf

[https://perma.cc/BFN7-ZWHC]. "Lodging" refers to the practice of submitting the application at the filing window at an individual immigration court, rather than attempting to file in open court. ImMigration Court Practice Manual $\S 3.1(\mathrm{a})(\mathrm{v})$. This permits the start of the "clock" for asylum seekers for work authorization purposes. Memorandum from Judge Brian M. O'Leary, supra at Attachment B. Essentially, asylum seekers are permitted to apply for an employment authorization document 150 days after they have filed an application for asylum. Id. When USCIS and EOIR were sued in late 2011 over the broken system of administering the "asylum clock," they agreed, by settlement to permit "lodging" of an asylum application at the court window, by mail or by hand, which would start the days counting on the asylum "clock" for purposes of obtaining an employment authorization document, or, a work permit. Settlement Agreement at 2, 16, B.H. v. U.S. Citizenship \& Immigration Servs., No. CV11-2108-RAJ (W.D. Wash. Nov. 4, 2013), https://www.justice.gov/sites/default/files/eoir/legacy/2013/09/27/ABT_Settlement_Ag reement_Redlined_092713.pdf [https://perma.cc/76QF-XJKD].

Within that settlement, the government made it very clear that lodging would not be automatically considered filing for the purposes of meeting the one-year deadline for asylum, but that individual judges could "consider the legal effect of an asylum application when considering whether an exception to the one-year bar applies." Memorandum from Judge Brian M. O'Leary, supra at 6.

EOIR never made clear the rationale behind their unwillingness to construe lodging as filing for one-year deadline purposes, but, in meetings in which the author has been present, EOIR officials have emphasized a need to defer to the discretion of individual immigration judges to adjudicate these issues on a case-by-case basis. Thus, lodging simply meant that a court clerk or administrator will stamp an I-589 as "lodged but not filed" to permit the start of the clock for work employment purposes. Id. at Attachment B. Some judges, however, construed lodging as filing for asylum purposes and some courts even went so far as to make it clear in pro bono liaison meetings with area practitioners that the court-wide policy was to accept lodging as filing. GROSSMAN \& HARRIS, supra note 126, at $7 \mathrm{n} .38$ (the judges at the immigration court in Arlington, Virginia, for example, have made such an announcement to local practitioners).

This clearly simplified the process and provided an easy way for the troublesome interplay between the deadline and the backlog to be remedied, but it only really provided this remedy for represented individuals. For pro se asylum seekers, it is unlikely that they would understand the nuances of lodging versus filing.

129. Grossman \& Harris, supra note 126, at 6. Attorneys with clients in removal proceedings without a timely court date also attempted to file applications affirmatively with USCIS with mixed results. Sometimes USCIS rejected the I-589 
(4) advancing arguments that undergoing a credible fear interview constitutes the filing of an asylum application. ${ }^{130}$

These practices, by and large, are no longer necessary given the recent policy change announced by the Office of the Chief Immigration Judge, discussed in the next section. However, unrepresented asylum seekers, the most vulnerable group, will likely not be aided-and may well be further disadvantaged-by the policy change.

\section{The CURRENT SituATION: AN INCOMPLETE SOLUTION DEEPENS THE Divide BETWEEN REPRESENTED AND PRo SE ASYlum SEEKERS}

\section{A. The EOIR Changes its Policy and Now Allows Filing of Asylum Applications at the Court Window}

On September 14, 2016, EOIR's Office of the Chief Immigration Judge issued a memo announcing a major policy change to allow asylum seekers to file their I-589 Applications for Asylum at the court window, rather than waiting to file at their scheduled master calendar hearing, ${ }^{131}$ which is often set beyond the one-year deadline. ${ }^{132}$ The

because their system reflected that an NTA has been issued and the asylum seeker is in removal proceedings. Asylum division Chief, John Lafferty, made clear that an I-589 will only be rejected if it is clear from their internal database that an NTA has been filed with the court, indicating that EOIR retains jurisdiction over the case. Meeting Agenda and Unofficial Notes for USCIS Asylum Division, Quarterly Stakeholder Meeting, AILA Doc. No. 15111204 (August 7, 2015), http://www.aila.org/infonet/uscis-asylum-division-liaison-minutes-08-07-15

[https://perma.cc/6L3S-7ZZH]. This is currently in question, however, as the San Francisco asylum office has issued letters claiming a lack of jurisdiction for asylum cases filed where the NTA has not yet been filed with the court. See Letter from S.F. Asylum Office, to author (Mar. 26, 2015) (on file with author).

Other times, USCIS initially accepted the I-589 but then rejected it at a later stage-after biometrics are taken or even a few days prior to interview. For example, two of the plaintiffs in the Mendez Rojas complaint filed their asylum applications affirmatively while they waited for DHS to place them in removal proceeding after passing credible fear interviews, and USCIS rejected both applications. Motion for Class Certification, supra note 110 (explaining that USCIS rejected applications for asylum from plaintiffs Rodriguez and Lopez because the agency assumed they were in removal proceedings, despite the fact that DHS had not filed the NTAs for either case with the immigration court prior to the deadline, and EOIR also rejected Mr. Rodriguez's attempted asylum filing for lack of jurisdiction because he was not in removal proceedings).

130. GROSSMAN \& HARRIS, supra note 126 , at 6, 8-9. This argument is still highly relevant and will be discussed in Part IV. Individuals who have undergone a credible fear interview, had no hearing scheduled prior to one year and no notice of the deadline, and missed the deadline, should still make this argument.

131. Memorandum from Michael C. McGoings, supra note 7, at 2.

132. GROSSMAN \& HARRIS, supra note 126 , at 1 . 
memo announces that EOIR will amend the Immigration Court Practice Manual $^{133}$ and "other guidance documents." 134

The change announced by EOIR, allowing for the filing of asylum applications at the court window, ${ }^{135}$ is a simple, logical fix. It will ease the cumbersome and onerous burden on attorneys to undertake measures to prove attempts to file, in the absence of an actual opportunity to file. The policy change will benefit asylum seekers represented by competent counsel, who, as long as their attorney files before the deadline with the court window, will unquestionably have met the one-year filing deadline, where this certainty was not possible before. Importantly, the change harmonizes practice throughout the nation's immigration courts and standardizes a procedure of accepting "lodging" as filing that had already been adopted in several courts across the country. ${ }^{136}$ Further, it was in the agency's own interest to make this change. In their report to the Administrative Conference of the United States, Lenni Benson and Russell Wheeler suggest that

133. Indeed, when the practice manual was first issued, the August 2009 cover memo by then-Chief Immigration Judge Brian O'Leary made clear that the document was "living." See ImMigration COURT Practice MAnual, Cover Memo (U.S. DEP'T OF JUSTICE 2016), https://www.justice.gov/eoir/pages/attachments/2015/02/02/practice_manual_review.pd f [https://perma.cc/K62Q-K8ZQ] ("The Immigration Court Practice manual is intended to be a 'living document' and the Office of Chief Immigration Judge updates it in response to changes in law and policy, as well as in response to comments by the parties using it.").

134. Memorandum from Michael C. McGoings, supra note 7, at 3.

135. Id. at 2. Curiously, EOIR did not abolish the "lodging" practice created by the A-B-T- settlement. Id. at 2-3. Most attorneys believe that an individual would be benefitted by both lodging and filing at the same time-i.e. starting the work authorization "clock" and simultaneously meeting the one-year deadline. In informal conversation, however, a few attorneys can see an advantage to being able to lodge an application sooner than filing. If, for example, the attorney and asylum seeker needed longer to fully flesh out the application and wanted to submit a more detailed version to the court for the purposes of filing, lodging may allow this. The court does not actually retain a copy of the lodged asylum application, but will do so when the application is filed. ImMigration Court Practice MANual $\S 4.15(1)(i)$. Under 8 C.F.R. $§ 208.4$ (c) (2016), an immigration judge or asylum officer can permit an asylum seeker to amend or supplement an application that has already been filed as a matter of discretion.

136. Complaint-Class Action for Injunctive and Declaratory Relief and Mandamus at 18, Mendez Rojas v. Johnson, No. 2:16-cv-01024-RSM $\begin{array}{lllll}\text { (W.D. Wash. July } & \text { filed }\end{array}$ https://www.nationalimmigrationproject.org/PDFs/practitioners/our_lit/2016_30Jun_roj as-v-johnson.pdf [https://perma.cc/Q45N-PE8J] (explaining that immigration judges in Omaha, Philadelphia, Charlotte, Cleveland, San Francisco, and Seattle allow lodging to constitute filing, but the Los Angeles court does not consider lodging as filing and in other courts, including Houston, Baltimore, Chicago, San Diego, New Orleans, Denver, and Portland, courts have made it clear that each immigration judge retains discretion to determine, on a case-by-case basis, whether lodging constitutes filing for one-year purposes). See supra note 128 for a more detailed explanation of "lodging." 
amending the practice manual to eliminate the requirement that asylum applications be filed in open court would increase immigration court efficiency. ${ }^{137}$

Why did it take EOIR so long to make this change? One of the agency's justifications for mandating the in-court filing of an asylum application was the need for an immigration judge to issue the "frivolous" advisal to asylum seekers-advising them of the consequences of filing a frivolous application for asylum, ${ }^{138}$ which can be a permanent bar on any and all immigration benefits in the United States. ${ }^{139}$ As the September 14, 2016 memo recognizes, this important advisal could be given at a later master calendar hearing or at the individual merits hearing. ${ }^{140}$ It is also worth noting that the I-589 Application for asylum itself includes the warning regarding the filing of a frivolous application in writing and requires the applicant to sign under penalty of perjury. ${ }^{141}$

This new approach is analogous to the affirmative asylum systemwhich provides no frivolous filing advisal at the time of filing. ${ }^{142}$ To file affirmatively, an asylum seeker simply signs the I-589, which includes the frivolous advisal, and then mails the application to a USCIS service center. ${ }^{143}$ The asylum seeker does not interact with a USCIS official until the day of the asylum interview, when the asylum officer gives them the warning and has them sign the application again. ${ }^{144}$ It appears that EOIR has come to recognize that an immigration judge can adequately give an in person frivolous filing advisal at the time that the application is about to be adjudicated at an individual hearing in open court. ${ }^{145}$

Although this rule change brings clarity and uniformity for asylum seekers represented by competent attorneys, without further reform from EOIR and USCIS, the rule is completely inadequate for pro se

137. Benson \& Wheeler, supra note 6 , at 79 .

138. INA § 208.4(d)(4), 8 U.S.C. § 1158(d)(4) (2012).

139. See 8. C.F.R. $\S 208.20$.

140. Memorandum from Michael C. McGoings, supra note 7, at 3. Further, the immigration court employee accepting the filing at the window could give the advisal orally and/or provide it in writing. See Benson \& Wheeler, supra note 6, at 79.

141. DeP'T OF Homeland SeC. ET AL., I-589 APPlication fOR AsYlum AND FOR WITHHOLDING OF REMOVAL 9 https://www.uscis.gov/sites/default/files/files/form/i589.pdf [https://perma.cc/KH3Y-KHSP] (lasted visited Oct. 23, 2016). The frivolous asylum application warning, along with a space for the asylum seeker to sign under penalty of perjury is found on page 9 of the I-589 Application form for asylum. See id.

142. Ndibu v. Lynch, 823 F.3d 229, 234-35 (4th Cir. 2016).

143. GROSSMAN \& HARRIS, supra note 126, at 2.

144. See DEP'T OF HoMELAND SEC. ET AL., , supra note 141, at 10 (providing a space for the asylum seeker to sign the application at an affirmative asylum interview (Part F) or a space for the asylum seeker to sign the application in court (Part G)).

145. Memorandum from Michael C. McGoings, supra note 7, at 3. 
asylum seekers. Unrepresented asylum seekers typically lack knowledge of not only the one-year deadline, but also the procedure for "lodging" or filing an asylum application at the immigration court window. ${ }^{146}$ Outside of the immigration context, eighty-nine percent of state-level trial judges surveyed by the American Bar Association in 2010 said that unrepresented litigants suffer from "procedural errors." ${ }^{147}$ Procedural rules, such as the technicalities around the oneyear filing deadline, can "govern a party's ability to gain initial access to the legal system." 148 The problems of a lack of representation for asylum seekers are likely even deeper, as asylum seekers are more likely to be non-English speakers and survivors of trauma. ${ }^{149}$ As it currently stands, the policy change does not offer meaningful relief for unrepresented asylum seekers, widening the gulf in outcomes between represented and pro se asylum seekers.

Further, the policy change introduces new uncertainties for those asylum seekers whose diligent counsel "lodged" an application with the court prior to September 14, 2016. Presumably the EOIR memo will benefit those who managed to "lodge" their asylum application at the court window prior to the one-year deadline and that judges will now construe that "lodging" as "filing," but the memo does not make that clear. ${ }^{150}$ Further, nothing in the EOIR memo discusses what will happen in the cases for individuals who lodged their applications with the immigration court window before the one-year deadline, and yet an immigration judge found them to be barred from asylum. ${ }^{151}$ Should

146. Complaint, supra note 136 , at 18 .

147. See Jessica K. Steinberg, Demand Side Reform in the Poor People's Court, 47 ConN. L. REV. 741, 756 (2015) (citing Linda Klein, Report on the Survey of Judges on the Impact of the Economic Downturn on Representation in the Courts (July 12, 2010)) (discussing the ABA 2010 study and explaining the procedural and substantive hurdles for pro se litigants in the civil context).

148. Id. at 795-96 (explaining how pro se litigants are "likely to default on any one of a number of procedural obligations they must fulfill in order to have their cases fully heard or to avail themselves of a remedy ordered by the court").

149. Id. at 758-59 (explaining that non-English speakers, individuals with mental disabilities, survivors of domestic violence, and overwhelmed single mothers are particularly disadvantaged as pro se litigants).

150. Memorandum from Michael C. McGoings, supra note 7, at 2-3.

151. Id. The Author is aware of a case in the Fifth Circuit in which this is precisely at issue. The following facts are recounted based on the Author's phone conversation with the attorney, Imran Beg Mirza, who runs a private practice in Houston, Texas, in late 2015 and email correspondence before that date. The asylum seeker did not timely file for asylum because he did not have a master calendar hearing scheduled within one year of his arrival. In that case, the attorney lodged the application at the court window and filed affirmatively, but did not file a motion to advance the master calendar hearing to permit timely filing. The immigration judge found that the applicant was barred from asylum for failure to meet the deadline and found the applicant did not meet the withholding standard. The BIA affirmed the 
those individuals file a motion to reopen? What if they are beyond the regulatory period to file such a motion?

The next section discusses two case studies that exemplify the injustice for pro se asylum seekers the September 2016 policy change did not address, and foreshadow the increasingly disparate outcomes for asylum seekers with and without competent representation absent additional reforms. Both of the asylum seekers discussed below were unrepresented until after their one-year filing deadline. Although both underwent credible fear interviews, neither received notice of the requirement to file an application for asylum, and both missed the filing deadline. In both cases, judges found no extraordinary circumstances to excuse the untimely filings, and both asylum seekers were barred from receiving asylum protection.

\section{B. Case Studies of Asylum Seekers Barred from Protection by the Deadline and Backlog}

No precedential decisions guide the adjudication of the one-year bar when it intersects with the immigration court backlog. The Board of Immigration Appeals (BIA) - the highest immigration-specific tribunal in the United States-and the United States Circuit Courts of Appeal have yet to address this issue. In this section, two case studies, from Maryland and Texas, highlight the issue and preview how, in the absence of further instruction from EOIR, similar outcomes could play out in asylum cases across the nation.

\section{SALVADORAN SURVIVOR OF DOMESTIC VIOLENCE BARRED FROM ASYLUM IN BALTIMORE}

Liana is a young mother and survivor of domestic violence from the Northern Triangle region of Central America. ${ }^{152}$ At age fifteen, Liana became involved with Manuel; while initially sweet and loving, Manuel quickly became jealous, possessive, and controlling. Liana became pregnant at the age of sixteen, dropped out of school, and

immigration judge's decision. In Khadiwal v. Lynch, No. 15-60310, 2016 WL 3611554, at *1, *4 (5th Cir. July 5, 2016), the Fifth Circuit affirmed the BIA's decision in a short per curiam opinion. The court declined to even reach the issue of the one-year deadline because, they said, the BIA had failed to reach the issue. $I d$. at $* 2$. The Author has attempted to contact the attorney on the case for the BIA decision and for further details but been has unsuccessful in receiving a response from the attorney.

152. Names have been changed to protect confidentiality and some details have been generalized or redacted. Liana consented to the use of her story in this Article. Feminine pronouns are used for all immigration judges or Board of Appeals members referenced. The Author currently represents Liana on appeal before the BIA and is personally acquainted with the facts in this case as Liana's representative. 
moved in with Manuel and his mother. Manuel forbade her from leaving the house and began to control and monitor her whereabouts. After the baby was born, Manuel raped Liana approximately three times a week, ripping off her clothes, and forcing himself on her, claiming it was his right as she was "his woman." Over seven years of repeated rapes, Manuel verbally abused Liana, repeatedly threatened her life, and became involved with the M-18 gang, a powerful transnational organization operating in El Salvador and throughout Central America. After one particularly violent incident in front of their child, Liana finally managed to leave the home she shared with Manuel. But, Manuel never accepted that she had left and, for the next two years, he harassed her: stalking her daily; calling her up to ten times a day, despite changing her phone number multiple times; physically assaulting a male co-worker with whom he suspected she was romantically involved; and arranged for a gang member friend to threaten to kill her if she did not return to him. Convinced that it was only a matter of time before these threats rang true and she would be killed, Liana left her mother, daughter, and sister in El Salvador and sought protection in the United States.

Liana entered the United States in October 2012 and, after a short initial period of detention, ICE released her on parole to join a family member in Maryland. She eventually underwent a credible fear interview in March 2013. There are two particularly notable aspects of Liana's credible fear interview. First, she was interviewed outside of detention. Most asylum seekers who undergo a credible fear interview are detained and may or may not be released after a positive decision is rendered. ${ }^{153}$ Second, Liana's prior attorney accompanied Liana to her credible fear interview. ${ }^{154}$ Before, during, and after that interview, the

153. Michele R. Pistone, Justice Delayed is Justice Denied: A Proposal for Ending the Unnecessary Detention of Asylum Seekers, 12 HARV. HuM. RTS. J. 197, 234 (1999). In July 2015, DHS Secretary Jeh Johnson made it clear that families undergoing the credible fear process would be released if a positive decision was rendered. Jeh Johnson, Written Testimony of DHS Secretary Jeh Johnson for a House Committee on the Judiciary hearing titled: "Oversight of the U.S. Department of Homeland Security," DEP'T OF Homeland SEC. (July 14, 2015), https://www.dhs.gov/news/2015/07/14/written-testimony-dhs-secretary-johnson-housecommittee-judiciary-hearing-titled- [https://perma.cc/K9UQ-6X2A].

154. INA $\S 235(\mathrm{~b})(1)(\mathrm{B})(\mathrm{iv}), 8$ U.S.C. $\S 1225$ (b)(1)(B)(iv) (2012) (“An alien who is eligible for such [credible fear] interview may consult with a person or persons of the alien's choosing prior to the interview or any review thereof, according to regulations prescribed by the Attorney General. Such consultation shall be at no expense to the Government and shall not unreasonably delay the process."); 8 C.F.R. $\S$ 208.30(d)(4) (2016) (adding that a representative may be permitted, at the asylum officer's discretion, to present a statement at the end of the interview); see also Memorandum from Joseph E. Langlois, INS Office of Int'l Affairs, to Asylum Directors, Supervisory Asylum Officers, Asylum Officers (Nov. 14, 1997). 
attorney failed to advise Liana as to the one-year deadline, and the asylum office also failed to give any instruction as to the deadline. ${ }^{155}$ The asylum officer determined that Liana had established a significant possibility of eligibility for asylum based on her fear of harm from her former partner, based on her membership in the particular social group of Salvadoran women unable to leave a domestic relationship. ${ }^{156}$ The asylum office issued a Notice to Appear (NTA) to Liana, referring her to immigration court to proceed with her application for asylum before an immigration judge. (It is worth noting that nothing in the NTA nor the asylum officer's interaction with Liana made clear that she should file an application for asylum in immigration court, and nothing made it clear that she had to within one year of her arrival in the United States in order to preserve her claim for protection.) While this NTA made clear that Liana was being referred to the Baltimore immigration court, it did not indicate a date, time, or judge before whom she was to appear. A second NTA, listing a judge, date, and time at which to appear in immigration court, was not actually issued until after Liana's one-year deadline in October 2013.

Liana obtained pro bono representation in January 2014 and filed her I-589 Application for Asylum shortly thereafter at the very first scheduled master calendar hearing, in February 2014. ${ }^{157}$ Despite extensive briefing and record evidence making abundantly clear the lack of a mechanism by which Liana could file her application within one year, the judge found that her asylum claim was barred by her failure to meet the one-year deadline. ${ }^{158}$ Specifically, the judge stated in her holding on the deadline:

155. A bar complaint was later filed against the law firm representing Liana at the credible fear interview with the District of Columbia's Bar.

156. For a detailed overview of the current state of asylum law as applied to survivors of domestic violence seeking protection, see Blaine Bookey, Gender-Based Asylum Post-Matter of A-R-C-G-: Evolving Standards and Fair Application of the Law, 22 SW. J. INT'L L. 1 (2016).

157. The Center for Applied Legal Studies, the asylum clinic at Georgetown University Law Center, provided pro bono representation. At the time, the Author served as a Supervising Attorney and Clinical Teaching Fellow within the clinic. The Author supervised the students handling the merits hearing, and the Author represented Liana pro bono on appeal before the BIA and currently on remand before the immigration court.

158. In assessing Liana's claim for withholding of removal, a lesser form of protection in the United States that does not require the filing of an application within one year of entry, the judge found that Liana was ineligible as he found that she was not a member of the particular social group of Salvadoran women unable to leave a domestic relationship. Matter of $V$-C-, (B.I.A. Apr. 2015) (on file with author). Specifically, the judge found that she had "left" the relationship because she physically stopped residing with her abuser, the father of her child, despite the fact that he stalked, harassed, threatened, grabbed her routinely, and had a gang member threaten to kill her. Id. at 9 . 
Looking first to the respondent's claim that essentially had the, as the Court understands it, had the court system been more efficient and she had a hearing at an earlier date, then she would have had an opportunity to file the application for asylum, and therefore she would not have missed the one-year bar, the Court finds no merit in that argument whatsoever. The process is such that she did not get the individual hearing date until a later time. Ignorance of the law is no excuse for failing to file an application for asylum. ${ }^{159}$

Although the immigration judge in this case relied on the maxim "ignorance of the law is no excuse," the judge fundamentally missed the point that even if Liana been aware of the law, there was no possible way for her to file on time because she did not have a master calendar hearing scheduled until after her one-year deadline.

Liana appealed the immigration judge's decision in her case to the BIA in May 2015. ${ }^{160}$ On November 1, 2016, the BIA issued an unpublished decision, reversing the immigration judge's decision on the one-year filing deadline. The Board stated:

Under the particular circumstances presented in this case, where the respondent filed her asylum application at the earliest opportunity at her initial master calendar hearing, the scheduling of which was outside of her control, we conclude that the 'extraordinary circumstances' test of section 208(a)(2)(D) of the Act has been satisfied and that the respondent filed her asylum application within a reasonable period given those circumstances. ${ }^{161}$

159. Id. at 7. A bar complaint was filed against the immigration law firm that represented Liana at her credible fear interview based in large part on their failure to advise her of the one-year deadline upon termination of services due to her inability to continue to pay their fees. Id. at 7-8. On that issue, the judge found that the attorney's passing mention of "something to do with one year" sufficed as effective assistance of counsel. Id.

160. The Author's briefing was accompanied by an amicus brief on the issue of the one-year deadline and the immigration court backlog, and a separate amicus brief on the underlying merits of Liana's gender-based asylum claim. The brief on the oneyear filing deadline and backlog was filed by Human Rights First and Akin Gump Strauss Hauer \& Feld, LLC (on file with author). The brief on the gender-based asylum issues was filed by the Center for Gender and Refugee Studies at the University of California, Hastings, School of Law (on file with author).

161. In $\quad r e: \quad V$ - $C$-, $\quad$ (B.I.A. Nov. $1, \quad 2016$ ) https://drive.google.com/file/d/0B_6gbFPjVDoxdy1faEs2MlJKT0U/edit [https://perma.cc/3M9H-DYFD] (on file with author). Daniel M. Kowalski, BIA Asylum Remand; El Salvador; Domestic Violence; One-Year Bar, LEXISNEXIS LEGAL 
The BIA reversed other erroneous findings by the immigration judge, finding Liana to be a member of the particular social group of "Salvadoran women unable to leave a domestic relationship" and remanding to a different immigration judge to consider the remaining issues in the case. Although this is a hopeful turn of events for Liana, the erroneous initial decision by the immigration judge led to more than a year-and-a-half's delay in adjudication, and the ultimate length of the delay is yet to be determined, as Liana's case still must be adjudicated on remand. Further, although the BIA issued a favorable decision on the one-year filing deadline, they did not designate the case as binding precedent, so the finding that filing at the first available master calendar where the hearing was set beyond the one-year deadline cannot meaningfully guide the consistent and efficient adjudication of this issue in other courts across the nation.

\section{HONDURAN SURVIVOR OF DOMESTIC VIOLENCE BARRED FROM ASYLUM IN TEXAS}

Yesenia, a native of one of the Northern Triangle countries of Central America, is a survivor of domestic violence at the hands of her partner. ${ }^{162}$ Yesenia's abusive partner subjected her to verbal, physical, and sexual abuse for two years. One particularly violent incident resulted in Yesenia miscarrying the couple's unborn baby. ${ }^{163}$ After this, her abuser kidnapped and held her for eight days, raping and verbally abusing her during that time. ${ }^{164}$ Receiving no help from the police, Yesenia fled. ${ }^{165}$

Yesenia arrived in the United States to seek protection in early July 2011. ${ }^{166}$ After a brief period of detention, during which time she underwent and passed a credible fear interview, Yesenia was released. She did not receive a date to appear in immigration court, however, until more than a year later, in October 2012, when she confirmed that she wished to apply for asylum and requested that the venue be changed

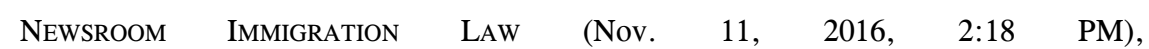
https://www.lexisnexis.com/legalnewsroom/immigration/b/insidenews/archive/2016/11 /11/unpub-bia-asylum-remand-el-salvador-domestic-violence-one-yearbar.aspx?Redirected = true [https://perma.cc/DLY8-2W8D].

162. Name and details have been changed to protect confidentiality, and in recognition of the sensitivities of discussing a case currently on appeal. The Author gained familiarity with Yesenia's case through contact with the attorney representing this individual on appeal.

163. Written Decision of Immigration Judge, at 6 (Tex. May 6, 2014) [hereinafter Yesenia IJ Decision] (on file with author).

164. Id.

165. Id. at 7 .

166. Id. at 5 . 
from one immigration court in Texas to another court much closer to where she was living. ${ }^{167}$ Yesenia's next immigration court hearing was scheduled for April 2013, where she requested more time to find representation. ${ }^{168}$ She appeared a month later, in May 2013, with counsel, and requested relief from removal in the form of asylum. ${ }^{169}$ She actually filed her I-589 application form for asylum on July 10, 2013. ${ }^{170}$

During her individual merits hearing before the immigration judge, Yesenia explained that she believed that she had filed for asylum when she underwent her credible fear interview and explained her fear of return to her home country. ${ }^{171}$ Further, she received no instruction telling her that she needed to file another application of any kind in order to apply for asylum. ${ }^{172}$

Despite the immigration judge's clear understanding of the fact that Yesenia was given no practical opportunity to file her asylum application and had expressed her fear of return during a credible fear interview, she found Yesenia barred from asylum. ${ }^{173}$ Yesenia's counsel argued that the language of the Immigration and Nationality Act and attendant regulations support construing undergoing a credible fear interview as "filing" for asylum. ${ }^{174}$ The judge, however, drew a technical distinction between "filing" an application and "initiating" the

167. Id. at 2, 6 ("The Court asked the Respondent if she wanted to proceed with her asylum application or if she preferred to apply for voluntary departure. The Respondent stated that she wished to apply for asylum. At that time, the Respondent's case was transferred to Dallas. No mention was made by the immigration judge regarding the Respondent's responsibility to file a documentary application for asylum. The Respondent discovered she was required to file a Form I-589 when she first appeared before the Dallas Immigration Court with her attorney. Her attorney informed her about the one-year filing deadline.").

168. Id. at 2 .

169. Id. at $2-3$.

170. Id. at 3 .

171. Id. at 5 .

172. Id.

173. Id. at 19 .

174. Id. at 13-14. INA $\S 235(\mathrm{~b})(1)(\mathrm{B})(\mathrm{ii}), 8$ U.S.C. $\S 1225(\mathrm{~b})(1)(\mathrm{B})(\mathrm{ii})(2012)$ ("If the officer determines at the time of the [credible fear] interview that an alien has a credible fear of persecution . . . the alien shall be detained for further consideration of the application for asylum.") (emphasis added). Yesenia's counsel also cited to the agreement between the United States and Canada regarding applications for asylum, which states that "[c]learly, then, the credible fear interview process constitutes the initiation of the asylum application process described in section 208(a)(1) o[f] the Act (8 U.S.C. 1158(a)(1))." Implementation of the Agreement Between the Government of the United States of America and the Government of Canada Regarding Asylum Claims Made in Transit and at Land Border Ports-of-Entry, 69 Fed. Reg. 69,480, 69,481 (Nov. 29, 2004). 
asylum process. ${ }^{175}$ The judge further found that the regulations are explicit in making clear that asylum applications must be filed on paper, so an "oral application made during a credible fear interview" would not constitute filing. ${ }^{176}$

Finding Yesenia barred from asylum by her failure to meet the deadline, the judge then considered whether her delayed filing was excused by an extraordinary circumstance under INA $\S 208(a)(2)(D)$. The judge concluded that there was no "unwarranted delay" by EOIR, despite the fact that Yesenia's initial master calendar was not scheduled until one year after arrival. ${ }^{177}$ The judge reasoned that although Yesenia's master calendar hearing was set beyond the one-year deadline, she could have found an attorney between the time of her release from detention and her filing deadline who would have "been able to inform her of the deadline and assist her in timely filing her asylum application." ${ }^{178}$ Finally, the judge ruled, just like the judge in Liana's case, "ignorance of the law does not excuse noncompliance therewith." ${ }^{179}$ To this judge, the fact that Yesenia was unaware of the filing deadline and thought she had filed for asylum was irrelevant to whether or not she would be permitted to pursue her application. ${ }^{180}$ The judge continued to consider Yesenia's eligibility for withholding of removal, which does not require filing within one year, but denied that claim due to a misunderstanding of the law and errors in applying asylum law to survivors of domestic violence. ${ }^{181}$

175. Yesenia IJ Decision, supra note 163, at 14 ("Section 208(a)(2)(B) of the Act requires that an alien demonstrate 'by clear and convincing evidence that the [asylum] application has been filed within 1 year after the date of the alien's arrival in the United States,' not merely that the asylum application process has been initiated.").

176. Id. at 15 (citing 8 C.F.R. § 1208.4 (2016) (explaining where asylum applications may be filed), and 8 C.F.R. $§ 1208.3$ (2016) ("an asylum applicant must file Form I-589") (emphasis added)).

177. Id. at 17 .

178. Id. at 18 .

179. Id.

180. Id. at $18-19$.

181. This particular immigration judge's errors in reasoning on a woman's "ability to leave" her relationship would be worthy of an entirely separate law review article. The particular social group in this case was defined as "Honduran women who are viewed as property by virtue of their positions in a domestic relationship" or "Honduran women in domestic relationships who are unable to leave." Id. at 19.

The Author notes, however, that this decision was issued in May 2014, prior to the BIA's precedent decision being issued in Matter of $A-R-C-G-, 26$ I. \& N. Dec. 388, 388-89 (B.I.A. 2014), making clear that "married women in Guatemala who are unable to leave their relationship" are a valid particular social group. The judge in this case would likely have been one to draw a distinction between a marital and non-marital relationship and took issue with the term "domestic relationship" as immutable, particular, and socially distinct, but perhaps the judge would have ruled differently 
In March 2016, the BIA affirmed the judge's denial of Yesenia's asylum. ${ }^{182}$ In dismissing the appeal, the BIA focused on whether Yesenia was a member of a cognizable particular social group, and distinguished the case from the BIA's precedent decision on domestic violence claims, issued in August 2014, Matter of $A-R-C-G-.{ }^{183}$ Because the BIA found that Yesenia was eligible for neither asylum nor withholding, the BIA member writing the decision found that the judge's decision regarding the one-year deadline did not violate her due process rights because it did not cause her substantial prejudice. ${ }^{184}$ Yesenia appealed the BIA's negative decision to the Fifth Circuit Court of Appeals. ${ }^{185}$

It is worth noting that both Yesenia and Liana are seeking asylum as women fleeing domestic violence at the hands of their partners and, in Liana's case, fear of harm from a transnational criminal organization in Central America. As previously mentioned, the asylum filing deadline disproportionately affects women, even prior to the immigration court backlog, further compounding the problem. These two cases are in fact quite representative of the current population of individuals seeking asylum protection in the United States. ${ }^{186}$

\section{Federal Court Challenge to the Lack of Notice and Opportunity to File}

The problem discussed in this Article posed by the one-year deadline and the immigration court backlog is in fact so widespread that on June 30, 2016, four asylum seekers filed a class action lawsuit in the Western District of Washington, challenging the lack of notice of the one-year deadline and the absence of a meaningful opportunity to file

post- $A-R-C-G-$ or at least had to work to distinguish Yesenia's case from that precedential decision.

182. Decision of the Board of Immigration Appeals, at 5 (Va. 2016) (on file with author).

183. Id. at $2-4$.

184. Id. at 5 .

185. Briefing in the case is currently stayed at the Fifth Circuit pending discussions between Yesenia's attorneys and the Office of Immigration Litigation. Email from Yesenia's att'y, to author (Sept. 26, 2016) (on file with author).

186. See generally United NATIONS High COMM'N FOR REFUGEes, WOMEN ON the Run: First-Hand Accounts of Refugees FleEing El Salvador, Guatemala, HONDURAS, AND MEXICO (Oct. 2015), http://www.unhcr.org/enus/publications/operations/5630f24c6/women-run.html [https://perma.cc/G9JU-G3GE] (exploring forced migration of increasing numbers of women from Central America and Mexico to the United States, fleeing violence at the hands of powerful gangs and violence in the home). 
within one year of arrival in the United States. ${ }^{187}$ Notably, this suit was filed prior to EOIR's September 14, 2016 policy change, and indeed the change may have been prompted by the lawsuit, which is ongoing at the time of writing this Article.

The case, Mendez Rojas v. Johnson, ${ }^{188}$ alleges that DHS violates the Immigration and Nationality Act, its implementing regulations, and the Administrative Procedure Act (APA) based on lack of notice of the one-year deadline. ${ }^{189}$ Further, the complaint alleges that this lack of notice is a violation of the Due Process Clause of the Fifth Amendment to the United States Constitution. ${ }^{190}$ Finally, the plaintiffs are suing all defendants, including departments within DHS-USCIS, ICE, CBP, and the Department of Justice-EOIR, for violations of the INA, APA regulations, and the Due Process Clause based on a lack of a uniform procedural mechanism by which to timely file an asylum application. ${ }^{191}$ The July 2016 motion for class certification is currently pending. ${ }^{192}$

This lawsuit has the potential to change the dynamics and provide relief for asylum seekers nationwide who did not receive notice of the one-year deadline and who were unable, procedurally, to file within one year. The plaintiffs' concerns have only partially been addressed by the EOIR policy change-now individuals with notice of the one-year deadline and the way in which to meet the deadline do indeed have a meaningful opportunity to file within one year. Currently, however, the United States government fails to give notice to asylum seekers of their obligation to file for asylum. Consequently, only individuals who secure competent legal representation are likely to actually meet the deadline by filing the I-589 application for asylum with the court window before the one-year mark.

187. Complaint, supra note 136. The case was brought by Northwest Immigrant Rights Project, National Immigration Project of the National Lawyers Guild, the American Immigration Council, and Dobrin \& Han, PC.

188. No. 2:16-cv-01024-RSM (W.D. Wash. filed June 30, 2016).

189. Id. at $35-37$.

190. Id. at 36-38. The Due Process Clause of the Fifth Amendment provides that "[n]o person shall . . . be deprived of life, liberty, or property, without due process of law .... U. U.S. ConST. amend. V. Plaintiffs argue that they have protected interests in applying for asylum and not being removed from the United States to countries where they fear persecution and that the Due Process Clause entitles them to a fair hearing of their asylum claim, including notice of the deadline to apply. Complaint, supra note 136 , at 35-38.

191. Complaint, supra note 136 , at 1-3.

192. Motion for Class Certification, supra note 110. 


\section{POTENTIAL SOLUTIONS}

The number of asylum seekers in the United States continues to grow, reflective of the worldwide trend of an increase in displaced persons. ${ }^{193}$ At the same time, the immigration court backlog shows no signs of abating, despite efforts to hire additional immigration judges. ${ }^{194}$ Following the 2016 Presidential election, Donald Trump has announced his plans to deport two to three million immigrants, which will, of course, further exacerbate the immigration court backlog. ${ }^{195}$ Despite the recent policy change announced through the Chief Immigration Judge's memo, asylum seekers unable to secure legal representation prior the one-year filing deadline still lack a meaningful opportunity to timely file their applications for asylum.

With pending class action litigation and a smattering of decisions at the immigration judge level, there is a growing need for a uniform and fair approach to this thorny problem, which looms large on the horizon. In short, the government's current practice makes it close to impossible for pro se asylum seekers to receive the due process to which they are constitutionally entitled in their removal proceedings.

This part of the Article outlines the necessary solutions to the brewing disaster described above, now most acute for pro se asylum seekers. Some of the solutions focus on addressing the one-year deadline specifically and some on the immigration court backlog. Both of these issues, as discussed throughout this Article, pose problems in other arenas and independently should be solved. But the interaction of the two has introduced new problems and the solutions below specifically target the result of this dangerous interplay. The first subsection discusses reforms to address the one-year filing deadline. The second sub-section discusses reforms aimed at addressing the immigration court backlog. The third and final sub-section proposes specific reforms-complementing the recently announced EOIR policy change and assuming that both the backlog and the one-year filing deadline continue to exist-to solve the problem caused by the interplay of those two phenomenas.

193. United Nations High Comm'n for Refugees, Global Trends:

FORCED DISPLACEMENT IN 2015 (2016),
https://s3. amazonaws.com/unhcrsharedmedia/2016/2016-06-20-global-trends/2016-0614-Global-Trends-2015.pdf [https://perma.cc/LDR6-HEQE] (sharing that a record high of over 65.3 million people are displaced worldwide).

194. Caldwell, supra note 2.

195. See Amy B. Wang, Donald Trump plans to immediately deport 2 million to 3 million undocumented immigrants, WASH. Post (Nov. 14, 2016), https://www.washingtonpost.com/news/the-fix/wp/2016/11/13/donald-trump-plans-toimmediately-deport-2-to-3-million-undocumented-immigrants/ [https://perma.cc/PP838PMG]. 


\section{A. Reforms to Address the One-Year Filing Deadline}

The most comprehensive, cleanest solution to the myriad problems posed by the one-year deadline is, of course, for Congress to repeal the deadline through a statutory fix. ${ }^{196}$ Numerous critics have repeatedly called for this overhaul, to no effect. ${ }^{197}$ Indeed, the most recent iteration of the Refugee Protection Act, re-introduced in July 2016, would specifically remove the one-year deadline. ${ }^{198}$ A legislative solution in the current political climate-amidst animus, suspicion, and fear directed towards immigrants, and towards refugees and asylum seekers more specifically-seems highly improbable. Thus, this Article focuses primarily on administrative solutions that can be taken in the absence of congressional action.

\section{B. Reforms to Reduce the Immigration Court Backlog}

Various agency actors within the immigration system and our government hold the power to alleviate the immigration court backlog.

\section{More PROSECUTORIAL DisCRETION BY DHS}

One clear way to reduce the immigration court backlog is for the government to be more selective about which immigrants are placed into removal proceedings. This would require DHS to retool its enforcement priorities and exercise prosecutorial discretion not to put as many immigrants into removal proceedings. Specifically, in recent years DHS and President Obama repeatedly claimed to focus on "felons, not families." 199 Despite this, the current enforcement

196. This has, of course, been proposed in various bills introduced in Congress over the years. See, e.g., Refugee Protection Act of 2010, S. 3113, 111th Cong. $\S 3$ (2010); Comprehensive Immigration Reform Act of 2010, S. 3932, 111th Cong. § 255 (2010); Restoring Protection to Victims of Persecution Act, H.R. 4800, 111th Cong. (2010).

197. Schrag et al., supra note 30, at 765 ("Congress should repeal the deadline for the sake of genuine asylum seekers, the efficiency and accuracy of asylum adjudication, and the reduction of unnecessary government expenditure."); Michele Pistone \& Philip Schrag, The New Asylum Rule: Improved but Still Unfair, 16 Geo. IMMIGR. L.J. 1, 31 (2001) ("The best solution would be to repeal the one-year deadline. . . ."); see also HeARTland Alliance ET AL., supra note 42, at 10-11; Human RIGHTS FIRST, supra note 29, at 42 (clearly stating that the deadline should be eliminated).

198. Refugee Protection Act of 2016, S. 3214, 114th Cong. $§ 3$ (2nd Sess. 2016); Refugee Protection Act of 2016, H.R. 5851, 114th Cong. $§ 3$ (2nd Sess. 2016) (eliminating the one-year deadline).

199. The White House Office of Press Sec'y, Remarks by the President in Address to the Nation on Immigration, WHITE House (Nov. 20, 2014), https://www.whitehouse.gov/the-press-office/2014/11/20/remarks-president-address- 
priorities include recent border crossers, who are largely women and children fleeing violence in Central America and seeking protection in the United States. ${ }^{200}$ DHS should retool its enforcement priorities and actually focus more narrowly on putting individuals with serious criminal convictions into removal proceedings. This shift in priorities would create additional bandwidth to adjudicate asylum and other claims for relief from removal that often must be adjudicated in immigration court. ${ }^{201}$

Further, DHS can limit the use of expedited removal, which contributes to the backlog in both the immigration courts and the asylum offices. ${ }^{202}$ In Matter of $E-R-M-\& L-R-M-,{ }^{203}$ DHS itself argued that it had discretion to not place individuals into expedited removal, and could instead place them directly into removal proceedings. ${ }^{204}$ As a matter of policy, the agency may also determine to not apply expedited removal to a group of individuals. For example, in 1997, the former Immigration and Naturalization Service (INS) announced that it would not place unaccompanied minors into expedited removal, instead charging them with grounds of inadmissibility that placed them in

nation-immigration [https://perma.cc/HA8J-C78U] ("Felons, not families. Criminals, not children. Gang members, not a mom who's working hard to provide for her kids. We'll prioritize, just like law enforcement does every day."); Remarks By Secretary of Homeland Security Jeh C. Johnson At Congressional Hispanic Caucus Institute 2015 Public Policy Conference, DeP'T OF Homeland SEC. (Oct. 7, 2015), https://www.dhs.gov/news/2015/10/07/remarks-secretary-homeland-security-jeh-c-

johnson-congressional-hispanic-caucus [https://perma.cc/S8WS-ELKN] ("Felons not families. Quality over quantity. Give people an opportunity to come forward and be held accountable, and be accountable.").

200. Memorandum from Jeh Charles Johnson, Sec'y of Homeland Sec., to Thomas S. Winkowski, Acting Dir., U.S. Immigration and Customs Enforcement et al. on Policies for the Apprehension, Detention, and Removal of Undocumented Immigrants (Nov. 20, 2014), https://www.dhs.gov/sites/default/files/publications/14_1120_memo_prosecutorial_disc retion.pdf [https://perma.cc/Z473-XG6V] (stating priority 2(c) to be "aliens apprehended anywhere in the United States after unlawfully entering or re-entering the United States and who cannot establish to the satisfaction of an immigration officer that they have been physically present in the United States continuously since January 1, 2014").

201. For fantastic explanations on the use of prosecutorial discretion in the immigration context, see SHOBA Sivaprasad WAdHIA, Beyond Deportation-The Role of Prosecutorial Discretion In IMmigration Cases (2015); Shoba Sivaprasad Wadhia, The History of Prosecutorial Discretion in Immigration Law, 64 AM. U. L. REV. 1285 (2015).

202. Frequently Asked Questions: Asylum Seekers and the Expedited Removal Process, HuM. RTS. FIRST (Nov. 2015), http://www.humanrightsfirst.org/sites/default/files/FAQ-asylum-seekers-and-theexpedited-removal-process.pdf [https://perma.cc/7DXZ-9CAQ].

203. 25 I. \& N. Dec. 520 (B.I.A. 2011).

204. Id. 
regular removal proceedings. ${ }^{205}$ In 2009 , ICE directed all field offices to no longer put immigrant families into expedited removal and to instead place them into regular removal proceedings. ${ }^{206}$ Reducing the number of expedited removals would assist in reducing the backlog because, currently, immigration judges must review any negative credible fear determinations issued by USCIS asylum officers. ${ }^{207}$ Further, immigration judges must oversee bond hearings for detained asylum seekers undergoing the credible fear process that results from claiming a fear in expedited removal proceedings. ${ }^{208}$ Thus, limiting the use of expedited removal where individuals have expressed a fear of return to their home country will help to reduce the backlog in immigration court.

205. See Michael John Carcia \& Kate M. Manuel, Cong. Research Serv., UnaCCOMPANied Alien Children: Current LaW Governing Removal From The United States and Selected Legislative Proposals 3 (2014) (“[I]mmigration authorities would generally charge arriving UACs who lacked proper documentation with a ground of inadmissibility for which expedited removal is not required, so that they could be placed in formal removal proceedings."). This practice was later codified with passage of the Trafficking Victims Protection Reauthorization Act (TVPRA) of 2008. 8 U.S.C. $§ 1232(a)(5)(D)$ (2012).

206. See Memorandum from David J. Venturella, Acting Dir., U.S. Immigr. and Customs Enf't, to Field Office Dirs. on Family Detention and Intake Guidance, 2 (Aug. 14, 2009) ("DHS has broad authority to decide whether to remove aliens through expedited removal . . . Effective immediately, discretion is to be exercised broadly in charging family unit cases so that they are placed in removal proceedings pursuant to Section 240 of the INA.").

Recently the DHS Advisory Committee on Family Residential Centers emphasized that:

DHS is not required to place families in expedited or reinstatement of removal, with their attendant policy of detention. There is clear authority for holding that immigration officials have the discretion to refer any individual who could be subject to expedited removal or reinstatement or removal to regular Section 240 removal proceedings before an immigration judge instead.

$\begin{array}{lllccrr}\text { REPORT OF } & \text { THE DHS } & \text { ADVISORY } & \text { COMMITTEE } & \text { ON } & \text { FAMILY } \\ \text { RESIDENTIAL } & \text { CENTERS } & 5 & (2016) & \text { (citations } & \text { omitted), }\end{array}$ https://www.ice.gov/sites/default/files/documents/Report/2016/ACFRC-sc-16093.pdf [https://perma.cc/V6AX-DGDS].

207. 8 C.F.R. $\S 208.30(\mathrm{~g})(2)(2016)$.

208. See Ruth Ellen Wasem, Cong. Research Serv., Rl41753, Asylum and “Credible Fear” Issues in U.S. IMMigration Policy 1 (2011). 


\section{FURTHER INCREASE THE NUMBER OF IMMIGRATION JUDGES AND JUDICIAL LAW CLERKS}

Significantly increasing the number of immigration judges and law clerks would also have the effect of reducing the backlog. ${ }^{209}$ Incremental progress has been made in this regard. For example, the federal budget for fiscal year 2016 included funding to support an additional fifty-five immigration judge teams. ${ }^{210}$ Funding has not, however, increased on-par with the need for adjudicators to address the current backlog. To truly address the immigration court backlog would require robust additional congressional appropriations, ${ }^{211}$ which has proven challenging over the years despite congressional readiness to increase the allocation of resources for the individuals targeting and apprehending immigrants to place into the removal hearings over which judges must preside. ${ }^{212}$ Funding has also dramatically increased for the detention of immigrants and asylum seekers. ${ }^{213}$

209. HumAn Rights FirST, supra note 99, at iv (advocating for Congress to authorize and appropriate funds to hire an additional 150 immigration judge teamsincluding law clerks and support staff-over a period of two years).

210. DeP'T OF Justice, FY 2016 Budget Summary 9, https://www.justice.gov/sites/default/files/jmd/pages/attachments/2015/02/02/2016_bud get_summary_pages_5-12.pdf [https://perma.cc/E29Q-FSDE] (last visited Aug. 26, 2016). Immigration Judge teams include "an immigration judge, a language specialist, a legal technician, a clerk, a law clerk, and one administrative support position. In addition, every two Immigration Judge Teams would share a BIA attorney and a paralegal." Joshua Breisblatt, The President's FY 2016 Budget, NAT'L IMMIGRATION FORUM (Feb. 6, 2015), https://immigrationforum.org/blog/the-presidents-fy-2016budget-department-of-justice/ [https://perma.cc/84S7-ZTZP].

211. Human Rights First recommends the hiring of an additional 150 immigration judge teams in FY2017 and FY2018 to address the backlog. See HumaN RIGHTS FIRST, Reducing the Immigration Court Backlog and Delays (July 2016), http://www.humanrightsfirst.org/sites/default/files/HRF-Backgrounder-ImmigrationCourts.pdf [https://perma.cc/7EHE-K7DL].

212. In recent years, funding has consistently increased for enforcement actions but not for the adjudication that necessarily results from that enforcement action. See Mark Noferi, DHS Funding Controversy Over, but Enforcement-First Approach Remains, IMMIGRATION IMPACT (Mar. 6, 2015), http://immigrationimpact.com/2015/03/06/dhs-funding-controversy-enforcement-firstapproach-remains/ [https://perma.cc/J8LU-NLH4]; see also AM. IMMIGRATION CouncIL, supra note 100; Benson \& Wheeler, supra note 6, at 32-33.

213. A huge amount of money in recent years, for example, has been funneled to detaining asylum-seeking families from Central America. See Chico Harlan, Inside the Administration's \$1 Billion Deal to Detain Central American Asylum Seekers, WASH. POST (Aug. 14, 2016), https://www.washingtonpost.com/business/economy/inside-the-administrations-1billion-deal-to-detain-central-american-asylum-seekers/2016/08/14/e47f1960-581911e6-9aee-8075993d73a2_story.html [https://perma.cc/Q9YH-UTCY] (explaining the one-billion dollar contract between ICE and Corrections Corporation of America (CCA) to build a new family detention center in Dilley, Texas, where CCA is paid 


\section{EMPOWER USCIS TO ADJUDICATE ASYLUM CASES ORIGINATING FROM POSITIVE CREDIBLE FEAR DETERMINATIONS}

To specifically reduce the number of asylum seekers contributing to the immigration court backlog, USCIS should be empowered to fully adjudicate asylum claims arising from credible fear interviews. Rather than referring all individuals who pass credible fear interviews into INA $\S 240$ removal proceedings before an immigration judge, DHS should instead amend their regulations in order to enable asylum officers to exercise discretion to retain jurisdiction over certain asylum claims and adjudicate those cases through the affirmative adjudication system. ${ }^{214}$ Some proposals go even further than this and suggest that EOIR amend its regulations to permit judges to administratively close cases where an applicant has asserted asylum or withholding of removal protection as a defense to removal, sending the case to the asylum office for initial adjudication. ${ }^{215}$ This extra step, of course, would

regardless of whether beds are actually occupied); see also Nick Miroff, Controversial Quota Drives Immigration Detention Boom, WASH. Post (Oct. 13, 2013), https://www.washingtonpost.com/world/controversial-quota-drives-immigrationdetention-boom/2013/10/13/09bb689e-214c-11e3-ad1a-1a919f2ed890_story.html [https://perma.cc/P52K-74BM] (explaining that ICE detains 34,000 immigrants on any given day).

214. The most recently proposed iteration is the Refugee Protection Act of 2016, S. 3214, 114th Cong. $\S 3$ (2nd Sess. 2016) (proposing that the asylum office has discretion to grant asylum under section 208 or refer to immigration court as necessary); Refugee Protection Act of 2016, H.R. 5851, 114th Cong. § 3 (2nd Sess. 2016) (stating that asylum officers conduct full asylum interviews and grant or refer applications for asylum, rather than conducting credible fear interviews and simply referring those with positive determinations to section 240 removal proceedings). This proposal has been made in various iterations over the years. In 2005, the United States Commission on International Religious Freedom recommended that asylum officers be empowered, in credible fear interviews, to grant asylum. Later, in 2010, the ABA Commission on Immigration recommended the same. Benson and Wheeler, in their report to the Administrative Conference of the United States, recommended the same. See Benson \& Wheeler, supra note 6, at 39 (recommending that USCIS amend 8 C.F.R. $\$ 235.6$ to allow asylum officers to adjudicate and approve asylum applications where a positive result for the applicant is clear at the credible fear stage and to refer to court if not); see also ElIZABETH CASSIDY \& TIFFANY LYNCH, BARRIERS TO Protection: The Treatment of Asylum Seekers in Expedited Removal, U.S. COMM'N ON INT'L RELIGIOUS FREEDOM 4, 54-55 (2016), http://www.uscirf.gov/sites/default/files/Barriers\%20To\%20Protection.pdf [https://perma.cc/GP6N-8W8D] (recommending that asylum officers are allowed "to convert and adjudicate appropriate cases in which credible fear is found as affirmative asylum cases").

215. Benson \& Wheeler, supra note 6, at 42-43. Note that this proposal also includes amending 8 C.F.R. $\S 208.16$ to allow asylum officers to grant withholding of removal protection. $I d$. at $47-50$. 
constitute an additional burden on the asylum office, ${ }^{216}$ but would advance the goal of reducing the immigration court backlog. Finally, allocating heavier responsibility to the asylum office, rather than the courts, would make sense from a budgetary perspective, as funding an asylum officer costs far less than funding a judge, a trial attorney, court personnel, and the interpreters required for adjudication of asylum claims in court. ${ }^{217}$

\section{Reforms to Specifically Address the Interplay of the One-Year Bar and the Backlog}

Assuming that Congress does not repeal the one-year deadline to apply for asylum and that the backlog of cases in immigration court persists, the DHS, EOIR, USCIS, ICE Office of Chief Counsel, and attorneys representing asylum seekers should take the following steps to prevent disastrous consequences for asylum seekers caught up in the procedural nightmare caused by the deadline and backlog combined.

\section{DePartment OF Homeland SECURITY}

\section{a. Expand the List of Extraordinary Circumstances}

DHS should immediately initiate the process to amend its regulations to expand the list of enumerated "extraordinary circumstances." 218 As discussed earlier in this Article, ${ }^{219}$ although it is

216. The Asylum Division is stretched very thin at present due to their mandate to conduct credible and reasonable fear interviews at the southern border for the increased numbers of asylum seekers, primarily from Central America, but has been able to double their corps of asylum officers in an attempt meet this challenge in the last few years, showing some promise of flexibility and efficiency in hiring to meet this challenge if needed. Indeed, adjudication of the asylum claim by the Asylum Office, under this proposal, may still be significantly delayed. The recently created Asylum Scheduling Bulletin reveals that some of the eight asylum offices nationwide are scheduling interviews more than four-and-a-half years after the filing of the asylum application. See Affirmative Asylum Scheduling Bulletin, U.S. CitizENSHIP \& IMMIGRATION SERVS., https://www.uscis.gov/humanitarian/refugeesasylum/asylum/affirmative-asylum-scheduling-bulletin [https://perma.cc/HYE6-YWJZ] (last visited Nov. 6, 2016).

217. Note that an asylum applicant is responsible for bringing her own interpreter, if needed, to an asylum interview with an asylum officer, whereas interpreters are provided at government expense in immigration court. See Immigration Court Practice Manual $§ 4.11$ (U.S. DeP’t of Justice 2016); see also Informational Guide fOR Prospective Asylum ApPlicants, U.S. Citizenship \& IMMIGRATION SERVS. (2012).

218. Schrag et al., supra note 30, at 766 (suggesting including the list of other possible extraordinary circumstances outlined in the Asylum Office Basic Training Course, discussed in supra note 33 , but also to include additional circumstances: "unawareness of the existence of the right to seek asylum; unawareness of the time 
clear by regulation that the listed extraordinary circumstances are not exhaustive, judges routinely fail to properly adjudicate even the listed exceptions. ${ }^{220}$

\section{b. Include a Limited Exception to the Deadline for Those Without Notice}

In Matter of $Y-C-{ }^{221}$ the BIA established a three-part test to determine whether an applicant's failure to file within one year of arrival was due to an extraordinary circumstance: ${ }^{222}$ first, the applicant must establish the existence of extraordinary circumstance; second, the applicant must show that those circumstances directly relate to her failure to timely file for asylum; third, the applicant must prove that the delayed filing was reasonable under the circumstances. ${ }^{223}$

In cases adjudicated prior to the September 2016 policy change in which an asylum seeker did not file her application in a timely manner, advocates could make a straightforward argument that she had no actual opportunity to file where their court date was set out beyond one year after their arrival. Logically, where the deadline was missed, attorneys argued that the failure of EOIR to provide a hearing date prior to one year constitutes an extraordinary circumstances exception to the deadline. Under the Matter of $Y$ - $C$ - framework, attorneys could argue that the extraordinary circumstance existed, that the lack of a court date directly delayed the filing, and that delayed filing was reasonable under the circumstances. While many judges seemed to accept this argument without objection, ${ }^{224}$ some judges completely dismissed the notion that

\footnotetext{
limit on applications; detention within the United States; fear that efforts to obtain the corroborating evidence necessary for a successful asylum application will endanger family members in the applicant's home country; victimization by a person other than an attorney, including a person pretending to be an attorney, who purported to be helping the applicant file an application; and inability, despite genuine and timely effort, to obtain a representative who could help compile the supporting evidence and file the application"); see also HeARTLAND Alliance ET AL., supra note 42, at 11; Pistone \& Schrag, supra note 197, at 33-34, 37 (suggesting additional examples of extraordinary circumstances be added to regulations, including the lack of awareness of the United States' asylum law or the deadline and an inability to obtain legal counsel); Philip G. Schrag \& Michele R. Pistone, The New Asylum Rule: Not Yet a Model of Fair Procedure, 11 GEO. IMMIGR. L.J. 267, 276 (1997) ("The INS should also include, in its illustrative list of changed circumstances, a genuinely belated discovery by the applicant of the existence of the U.S. asylum system or the application deadline.").

219. See supra Part III.B.2.

220. The enumerated extraordinary circumstance exceptions to the one-year filing deadline for DHS are currently found at 8 C.F.R. $§ 208.4(a)(5)(i)-(i v)$ (2016).

221. 23 I. \& N. Dec. 286, 288 (B.I.A. 2002).

222. Id.

223. Id.

224. Complaint, supra note 136, at 19-20.
} 
the administrative scheduling delays caused by the immigration court backlog could be an extraordinary circumstance exception to the oneyear deadline. Indeed, in Liana and Yesenia's cases discussed in Part III, the judges rejected these arguments wholesale, incorrectly understanding them to be the respondents' own "ignorance" of the law. It is notable, however, that the BIA found in Liana's case that the inability to file within a year due to a lack of scheduled court hearing was an extraordinary circumstance beyond Liana's control that excused the untimely filing of her asylum application. ${ }^{225}$

The expanded list of extraordinary circumstances, thus, should not only include the additional list of extraordinary circumstances included in USCIS Asylum Office training materials, ${ }^{226}$ but also include a limited exception for individuals who lack notice of the requirement to file within one year of arrival in the United States. To be clear, this exception should apply where

1) the asylum seeker lacks notice of the filing deadline; ${ }^{227}$

2) the NTA was issued and filed with the immigration court before the one-year filing deadline, ${ }^{228}$ and

3) the initial master calendar hearing was set for a date after the one-year filing deadline.

Failure to provide instruction to immigration judges on this issue will result in unfairness, as evidenced in Liana and Yesenia's cases, where an individual judge can bar asylum based on an unwillingness to consider an extraordinary circumstances argument.

This fix would be in line with congressional intent in enacting the one-year deadline in the first place. Indeed, one legislator involved in the passage of the one-year deadline clearly expressed his belief that asylum seekers would be clearly informed of the deadline to apply. ${ }^{229}$

225. See supra note 161.

226. These were mentioned in Part II of this Article. See supra note 34 and accompanying text.

227. This lack of notice should apply regardless of whether or not the asylum seeker underwent a credible fear interview-if she expressed a fear of return to her home country and was released from detention with a Notice to Appear in immigration court-she should be deemed an asylum seeker entitled to notice of the deadline. See Complaint, supra note 136, at 11-13 (detailing "other entrants" as those asylum seekers who were not referred for a credible fear interview upon arrival in the United State and were instead "paroled" from detention with a NTA referring them directly to removal proceedings).

228. There are often delays where ICE does not file the NTA with the immigration court for months, or even more than a year. See Complaint, supra note 136 , at 3 .

229. Khandwala et al., supra note 29 , at 5 ("[T]he chief House sponsor of the deadline, Rep. Bill McCollum, stated: 'The Immigration Service would be required to tell people who came in that they could apply for asylum and this is how long it would take. Well it may not be in the legislation but it's certainly going to be in the report 
Despite this, it has never been agency practice under the former INS, or under any branch of the current DHS, to inform asylum seekers of their duty to apply for asylum within one year of arrival. The failure to inform should be remedied, as discussed below, but the consequences of that failure should be ameliorated by giving immigration judges clear power and instruction to consider a lack of notice, and therefore knowledge, of the requirement to file as an extraordinary circumstances exception to the one-year deadline. It is simply untenable for the United States government to continue its absolute failure to advise asylum seekers of their responsibility to file within one year of arrival and then to later penalize them for their lack of knowledge of the precise workings of the complex asylum adjudication system.

\section{UNITED STATES CITIZENSHIP AND IMMIGRATION SERVICES}

\section{a. Mandate a One-Year Bar Advisal for Asylum Seekers with Positive Credible Fear Determinations}

USCIS should issue advisals to all individuals who pass credible fear interviews, making it abundantly clear the steps that the individual must undertake to actually file an application for asylum and to do so within one year after the asylum seeker's last arrival into the United States. The Author has led efforts with advocates to draft such advisals, which were delivered to the asylum office in April 2016. ${ }^{230}$ Advocates recommended that these advisals be provided in both oral and written form, in the asylum seeker's primary language. Among other information, the advisals would make clear that the asylum seeker must take additional steps to file for asylum and would make clear to the asylum seeker precisely how and where to go about filing. ${ }^{231}$

language and I think the Immigration Service is going to do that.' Unfortunately, the Committee Report did not include such language, and the INS did not adopt the policy of informing potential asylum seekers of the deadline.").

230. At the November 4, 2016 USCIS Asylum Division Quarterly Stakeholders Meeting, USCIS declined to comment on the status of the advisals given the pending Mendez-Rojas litigation. Formal meeting notes have not yet been issued but informal notes, taken by American Immigration Lawyers Association National Asylum and Refugee Liaison Committee Co-Chair, Sandra Grossman, are on file with the author.

231. To actually facilitate pro se filings at the court window prior to the deadline, USCIS, the creator and keeper of the I-589 application for asylum, should make the form available in other languages, and EOIR should amend the Immigration Court Practice Manual to accept these foreign language forms. The asylum office already makes certain materials available in other languages-for example an asylum seeker is able to receive her asylum approval letter in one of the ten most common languages spoken by asylum seekers. Providing the form itself in the relevant languages would assist in the expeditious completion and filing of the asylum application, regardless of whether legal counsel or competent interpretation can be accessed and retained within one year after arrival. Of course there are costs involved with issuing 


\section{EXECUTIVE OFFICE FOR IMMIGRATION REVIEW}

To its credit, EOIR is the first agency to take any steps to attempt to remedy the unfair and troubling consequences of the one-year filing deadline and the immigration court backlog combined. But to offer a meaningful solution, the agency's September 14, 2016 policy announcement must be just the first in a constellation of reforms to address this issue. Without further reform, the policy change actually works to further disadvantage pro se asylum seekers. Recognizing asylum applications filed at the court window as filed for the purposes of the deadline advantages only those asylum seekers who know about this new rule. Given the lack of notice given to asylum seekers on the one-year deadline and the mechanics of filing, asylum seekers represented by competent counsel are far more likely to file an application at the court window. Pro se individuals remain unlikely to file and to understand that there is anything they must do to initiate their asylum claim other than wait for their court date, which may be scheduled years into the future.

Prior to the bright-line rule recognizing window-filing as filing for one-year purposes, many judges exercised discretion in finding an extraordinary circumstances exception to the deadline, which benefitted pro se and represented individuals who missed the deadline due to no fault of their own when a hearing was not timely scheduled. Now that the hearing is not the only time that an asylum seeker can file, judges may hesitate to exercise that same discretion to find an extraordinary circumstance to excuse untimely filing exists.

and accepting the I-589 form in multiple languages, so the cost of such a fix should be considered when weighed against larger rule changes, such as adjudicating credible fear claims as full asylum claims in the first instance.

Although the ramifications of accepting filings in different languages without translations are potentially complex, language should not be a barrier to an individual timely filing an application. Further, rules could be implemented to simplify the logistical challenges and financial burden on the court-for example, requiring a translation to be submitted prior to the merits hearing on the asylum claim in order for the claim to be adjudicated. But, the cost of even just initially accepting the form in multiple languages may be prohibitive given that judges would likely wish to verify that there was a possibility of eligibility for asylum prior to scheduling a merits hearing. And so, translation on the part of the court may be required (the burden of written translation is usually on the asylum seeker and all respondents in immigration court, see Immigration Court Practice Manual $§ 3.3 \mathrm{a}$ (U.S. DeP’t of Justice 2016)) and may be expensive or logistically challenging. Therefore, the relatively costless solutions outlined within this Part of the Article-ensuring asylum seekers receive notice and issuing instructions to immigration judges on administrative delays caused by the backlog as an extraordinary circumstances exception to the one-year deadline-should be the high priority solutions EOIR and USCIS implement to address this eminently solvable problem. 
Prior to the September 14, 2016 policy change, courts and judges across the nation varied as to how they handled the interplay between the asylum one-year filing deadline and the immigration court backlog, as well as how they approach lodging, filing, motions to advance, extraordinary circumstance exception arguments, and other legal arguments on this issue. ${ }^{232}$ EOIR has refused to disclose detailed information regarding how these issues are addressed nationwide. ${ }^{233}$ Anecdotally, however, and from the information gathered to support the Mendez Rojas class action lawsuit, it is clear that immigration courts-and indeed, individual judges-across the nation varied greatly in terms of their approach to the interplay between the one-year deadline and the immigration court backlog. ${ }^{234}$ The result, of course, was a further extension of the phenomenon coined by Professors RamjiNogales, Schrag, and Schoenholtz as "refugee roulette" ${ }^{235}$ - the inconsistent adjudication of asylum claims nationwide. In one courtroom, an individual who missed the deadline due to a lack of opportunity to file in court before the deadline was found to be asylum eligible and deadline excused, while in another, she is barred from asylum.

Given the lack of detailed guidance on the implementation of the September 14, 2016 policy change and how it applies to individuals who already missed the deadline, whether or not they "lodged" or did not lodge at the court window, the risk of "refugee roulette" remains. ${ }^{236}$

232. Complaint, supra note 136 , at 19-20.

233. In an effort to understand the breadth of this problem, the Author developed a short survey to administer with the court administrators at all fifty-seven immigration courts, throughout the nation. Unfortunately, however, EOIR's Public Affairs office made it clear that court administrators would not respond to these basic questions (which included simply whether their court had any cases scheduled for master calendar hearings beyond the one-year deadline) because of pending litigation. Absent clarification, which the Author requested, from EOIR, the Author can only assume that this pending litigation must refer the Mendez Rojas lawsuit, discussed above, which challenges the government's failure to advise asylum seekers of the oneyear deadline and to provide a meaningful opportunity to file the application within that one-year period. See E-mail from Kathryn Mattingly, Assistant Press Secretary in EOIR's Office of Communications and Legislative Affairs, to author (July 27, 2016, 5:04 PM) (on file with author) ("This matter is currently under litigation so we cannot participate.").

234. Complaint, supra note 136, at 3.

235. JAyA RAmu-Nogales ET AL., RefugeE Roulette: Disparities IN AdJUdiCATION AND PROPOSALS FOR REFORM (2009).

236. The memorandum does not make clear, for example, whether an individual who lodged their asylum application at the court window prior to the September 14, 2016 policy announcement permitting filing at the window, would then be considered to have filed, or whether they would still be barred from asylum eligibility and bear the burden of proving an exception to the one-year filing deadline was warranted by their individual circumstances. Memorandum from Michael $\mathrm{C}$. McGoings, supra note 7. 
The disparities in how the one-year filing deadline applies, however, will largely be along the lines of represented versus unrepresented individuals, those who were informed about the deadline-thanks to securing competent legal counsel-and those who remained in the dark.

\section{a. Provide Advisals Following Positive Credible Fear Interviews and at the First Scheduled Master Calendar Hearing}

To properly effectuate reform, EOIR must first, like USCIS, issue advisals to individuals who receive a positive credible fear determination. Where the asylum division issues a negative decision following a credible fear interview, the asylum seeker has the opportunity to go before an immigration judge for a review of that decision. ${ }^{237}$ In the event that the immigration judge vacates the asylum officer's negative determination and issues a positive decision, the immigration judge should be responsible for advising the asylum seeker, orally and in writing, as to the requirement to file for asylum within one year of arrival in the United States and precisely how to go about doing so.

Further, where an asylum case is not affected by the immigration court backlog and an asylum seeker appears at a master calendar hearing scheduled before her one-year deadline, the immigration judge likewise has a duty to advise an asylum seeker of the one-year deadline. ${ }^{238}$ Under the existing regulations, the immigration judge should make clear, to any individual who has expressed a fear to United States immigration officials or undergone a credible fear interview, that she must file an I-589 Application for Asylum at the court window or in court within one year after her arrival in the United States. Ensuring conformity with these required advisals can be achieved through a memo from the Chief Immigration Judge, advising immigration judges of their affirmative duty to notify asylum seekers who meet the credible fear standard of the one-year deadline and how to file.

237. INA $\S 235(\mathrm{~b})(1)(\mathrm{B})(\mathrm{iii})(\mathrm{III}), 8$ U.S.C. $\S 1225$ (b)(1)(B)(iii)(III) (2012); 8 C.F.R. $\S 208.30(\mathrm{~g})(2)(2016)$.

238. This comports with an immigration judge's duty to inform noncitizens in removal proceedings of their "apparent eligibility to apply for any of the benefits enumerated in this chapter." 8 C.F.R. $\S 1240.11(a)(2)$ (2016). Under 8 C.F.R. $\S$ 1240.11(c)(1), where a noncitizen expresses a fear of persecution (which any asylum seeker would have done if they have undergone a credible fear interview), then the judge must, under (c)(1)(i), "[a]dvise the alien that he or she may apply for asylum," and under (ii) "[m]ake available the appropriate application forms." 


\section{b. Implement a Limited Exception for Lack of Notice and Expand Exceptions to the One-Year Deadline}

As discussed above with regards to DHS, EOIR must also expand the list of circumstances qualifying as exceptions to the filing deadline further ${ }^{239}$ to include individuals who can demonstrate that they lacked notice, and thus knowledge of the deadline. ${ }^{240}$ Although it is clear under the regulations that the list of extraordinary circumstances exceptions to the one-year deadline is non-exhaustive, some immigration judges have been reluctant to find that an administrative delay in scheduling a master calendar hearing - to permit an individual to timely file for an asylum-constitutes an extraordinary circumstance. Examples of this intransigence and the resulting bar to protection for asylum seekers were discussed earlier in this Article with the cases of Yesenia and Liana. These same judges will likely find that any asylum seeker who failed to file her asylum application at the window, following the September 14, 2016 announcement, has missed the filing deadline and that failure to file cannot be excused, even if she lacked any notice of the requirement to file within a year.

Because rulemaking is a time-consuming process, in the meantime, there are two ways that EOIR can provide the guidance needed to immigration judges on this issue. First, the BIA recently issued an unpublished decision, discussed above, as "Liana's case." ${ }^{241}$ In that decision, the BIA made clear that a failure to meet the filing deadline because a master calendar was scheduled beyond the one-year filing deadline met the extraordinary circumstances "test" under INA $\S$ 208(A)(2)(D). The BIA should designate this decision as a precedent decision to provide this guidance to immigration judges nationwide.

A second critically important and long-overdue step is for the EOIR or the Office of Chief Immigration Judge to issue instructions for immigration judges on this issue. Given the volume of cases currently being adjudicated, the agency cannot wait for the rulemaking process to

239. Advocates have long recommended that EOIR adopt the USCIS Asylum Office's training materials and expanded list of extraordinary circumstances to be considered as exceptions to the one-year deadline. Heartland Alliance et AL., supra note 42, at 10 ("DOJ should immediately adopt Asylum Office guidance that lists additional circumstances that can constitute statutory exceptions to the deadline, beyond those listed in the regulations.").

240. The current regulations on extraordinary circumstance exceptions to the one-year deadline are found at 8 C.F.R. $\S 1208.4(a)(5)(i)-(v i)$ (2016). The proposed exception discussed above, supra Part IV.C.1.a, for DHS, should also be added to the regulations for EOIR. HEARTLAND ALLIANCE ET AL., supra note 42, at 11 ("DOJ and DHS should give particular consideration to whether individuals who were reasonably unaware of potential eligibility for asylum protection can demonstrate an exception to the deadline.").

241. See supra note 161. 
conclude. These instructions should make absolutely clear that a failure to meet the one-year deadline because an individual lacked notice of the requirement to file and her first court date was set beyond the deadline, qualifies as an extraordinary circumstances exception to the deadline. ${ }^{242}$ EOIR should also make clear that where an individual has undergone a credible fear interview, or expressed her fear to a United States immigration official, ${ }^{243}$ her application for asylum should be deemed "filed" for the purposes of the one-year deadline.

It is difficult to understand why it took EOIR so long to take any action to protect asylum seekers from the rejection of their asylum applications based on a technicality in scheduling and filing beyond their control. Now, however, the agency has taken action that is incomplete and may actually exacerbate the inequities in the system. Previously, judges could find extraordinary circumstances exceptions for individuals who failed to meet the one-year deadline due to a lack of a scheduled master hearing and thus no opportunity to file. Now, individuals technically have an opportunity to file because filing at the window before the one-year deadline counts. This opportunity is not,

242. Efforts in the past year or so to push EOIR to issue such guidance have been unsuccessful. These efforts included a formal letter drafted by Akin Gump Strauss Hauer \& Feld, LLP, and Human Rights First, urging EOIR action to remedy the problem of the deadline combined with the backlog (on file with author). The Author was present at meetings with the White House Office of Public Engagement between July 2015 and June 2016 during which Nathan Berkeley, a spokesperson for EOIR made it very clear that the agency was unwilling to issue any guidance for immigration judges on the matter of the filing deadline and the immigration court backlog. This has been superseded, somewhat, by the September 14, 2016 memo from the Acting Chief Immigration Judge. Memorandum from Michael C. McGoings, supra note 7. American Immigration Lawyers Association's EOIR liaison committee also raised these issues with EOIR and received the following response:

EOIR does not intend to issue additional guidance at this time regarding the effect of timely lodging an asylum application on the one-year filing deadline for such applications. The guidance with respect to this issue, provided on page 6 of OPPM 13-03, clearly states, 'Legal determinations regarding the effect of lodging an asylum application are within the province of the presiding Immigration Judge. For example, judges may consider the legal effect of lodging an asylum application when considering whether an exception to the one-year bar applies.' In cases where an asylum application is untimely filed, judges decide whether the 'extraordinary circumstances' exception to the filing deadline applies on a case-by-case basis.

Meeting Agenda and Unofficial Notes for USCIS Asylum Division, supra note 129.

243. Not all individuals who express a fear when apprehended by Customs and Border Protection or when arriving at the border actually receive a credible fear interview. In fact, many are released on parole into the United States simply with a Notice to Appear in immigration court to pursue their claims for relief, including asylum. Revised Parole Policy for Arriving Aliens with Credible Fear Claims, U.S. IMMigRATION \& CUSTOMS ENF'T (Dec. 16, 2009), https://www.ice.gov/factsheets/credible-fear [https://perma.cc/9PMJ-FSGA]. 
however, helpful for asylum seekers nationwide who lack competent representation.

EOIR may be resistant to giving immigration judges instructions as to how to rule on extraordinary circumstance exceptions to the filing deadline. In meetings with advocates, EOIR previously asserted that it did not want to interfere with an individual immigration judge's discretion to determine whether filing late because of a lack of a hearing before the one-year deadline constituted an extraordinary circumstance to excuse late filing. ${ }^{244}$ While a judge's discretion is no doubt important and deserves deference in many contexts, this is not one of them. An overwhelmed and overburdened agency unable to provide hearings in a timely manner to enable pro se asylum seekers to meet their filing obligation cannot ethically penalize asylum seekers for their failure to somehow discern that they must file an official application for asylum within a year. EOIR should, of course, protect immigration judge discretion when it comes to the substance of an asylum claim, the credibility of an individual asylum applicant before the judge, and other important determinations that vary between cases. It is in EOIR's own self-interest, however, to create a uniform, efficient, and fair system for the adjudication of missed one-year filing deadlines for as long as the lack of notice to asylum seekers and the backlog persists. The only way to do so is to create uniform rules for immigration judges to follow, which include a lack of notice as an extraordinary circumstance exception to the one-year deadline.

\section{c. Provide Maximum Due Process for Unrepresented Asylum Seekers}

Absent clear instruction from the Office of the Chief Immigration Judge, individual immigration judges should exercise their discretion in favor of ensuring access to justice for pro se asylum seekers. The Immigration Court Practice Manual itself encourages immigrants appearing in immigration court to retain an attorney. ${ }^{245}$ Section 2.2(a) of the manual states, "Due to the complexity of the immigration and nationality laws, the Office of the Chief Immigration Judge recommends that those who can obtain qualified professional representation do so." ${ }^{446}$ Section 2.2(b) explains that judges are obligated to provide a list of pro bono legal service providers to respondents appearing without counsel. ${ }^{247}$ Where an asylum seeker has

244. Immigration Court Practice Manual $\S 3.1$ (b)(iii) (U.S. DeP'T of JUSTICE 2016).

245. Id. $\S 2.2(\mathrm{~b})$.

246. Id. § $2.2(\mathrm{a})$

247. Id. $\S 2.2(\mathrm{~b})$. In addition, the government is always represented by a trained prosecutor in immigration court. Id. $\S 1.2(\mathrm{~h})$. As Professor Engler explains, 
not been able to secure counsel prior to the one-year filing deadline, then immigration judges must adjust their behavior accordingly. ${ }^{248}$ While recommendations could be made that court staff-including the court administrator, filing clerks, and law clerks-become involved in disseminating information and guidance to pro se asylum seekers, this line of thinking is impractical, as generally asylum seekers have no reason to come to the court location if their hearing date is not scheduled until further into the future, beyond their one-year filing deadline. Such assistance, thus, would be futile. Therefore, without proper notice of the filing requirement, accommodations must be made on the back-end, once the deadline has already been missed, to protect the rights of pro se asylum seekers.

Much of the access to justice literature argues that judges presented with pro se litigants have a responsibility to engage in "active judging," which can be broken down into three main categories: (1) adjusting procedures; (2) explaining law and the legal process; ${ }^{249}$ and (3) eliciting information. ${ }^{250}$ In this circumstance, active judging means adjusting procedures and finding that where an individual has expressed their intent to apply for asylum-often actually explained their fear of return to an asylum officer-yet failed to submit an official form applying for asylum to the court window before one year, that

"[c]ases involving a represented party against an unrepresented one presented the greatest challenge to maintaining impartiality." Russell Engler, Ethics in Transition: Unrepresented Litigants and the Changing Judicial Role, 22 NotRE DAME J.L. ETHICS \& PUB. POL'Y 367, 372 (2008).

248. See Engler, supra note 247, at 372-74 (explaining that, generally, courts must take into account the needs of self-represented litigants).

249. Immigration judges are required to advise noncitizens of their rights in proceedings. See 8 C.F.R. § 1240.10(a) (2016).

250. Anna E. Carpenter, Active Judging and Access to Justice 7 (unpublished manuscript) (on file with author). Immigration judges already have some duty to engage in active judging through their duty to develop the record under INA $\S 240(\mathrm{~b})(1)$, which requires immigration judges to "administer oaths, receive evidence, and interrogate, examine, and cross-examine the alien and any witnesses." INA $\S$ 240(b)(1), 8 U.S.C. $§ 1229 a(b)(1)$ (2012). The regulations further reinforce this and also require immigration judges to take other actions that are "appropriate and necessary for the disposition” of an individual case. 8 C.F.R. $§ 1003.10$ (b) (2016).

The Board of Immigration Appeals has further reinforced these duties through case law. See Matter of E-F-H-L-, 26 I. \& N. Dec. 319, 323-24 (B.I.A. 2014) (finding that the regulations require a full hearing on the merits to adjudicate an asylum claim and this duty is reinforced by the judge's statutory duty to develop the record); Matter of J-F-F-, 23 I. \& N. Dec. 912, 922 (Att'y Gen. May 1, 2006) (“It is appropriate for Immigration Judges to aid in the development of the record, and directly question witnesses, particularly where an alien appears pro se and may be unschooled in the deportation process ...."). 
individual should be deemed to have met the technical requirement of "filing" for asylum for the purposes of the one-year deadline. ${ }^{251}$

\section{ICE ASSISTANT CHIEF COUNSEL}

The exercise of prosecutorial discretion not to put individuals into removal proceedings in the first place is discussed above as one way in which the immigration court backlog could be reduced. In a separate but similarly important manifestation of prosecutorial discretion, where an asylum case is before the court, ICE trial counsel should exercise the power to stipulate to asylum where it is clear that an individual clearly meets the definition of a refugee but has simply missed the deadline due to the lack of an opportunity to timely file for asylum in open court. Trial counsel could also stipulate just to the discrete issue that the asylum application was timely filed or that an exception has been met, particularly in situations where the asylum applicant expressed their fear to the United States government prior to the one-year deadline. This would comport with an ICE attorney's duty to faithfully uphold American laws, which includes ensuring that no individual is returned to a country where she would face a threat to her life or freedom, or, indeed a well-founded fear of persecution.

251. Cynthia Gray, Am. Judicature Soc., Reaching Out OR OverReaching: Judicial Ethics AND Self-RePresented Litigants 1, 5 (2005), http://www.courts.ca.gov/partners/documents/ReachingOutOverreaching.pdf [https://perma.cc/ZQ5S-P849] ("A judge should take pains to protect self-represented litigants against the consequences of technical errors" and "[U]nder the code of judicial conduct, no reasonable question is raised about a judge's impartiality when the judge, in an exercise of discretion, makes procedural accommodations that will provide a diligent self-represented litigant acting in good faith the opportunity to have his or her case fairly heard - and, therefore, that a judge should do so.").

But see Rebecca A. Albrecht et al., Judicial Techniques for Cases Involving SelfRepresenting Litigants, 42 JudGES J. 16, 44 (2003) (synthesizing the guidance from cases on the role of a judge in adjudicating cases involving pro se litigants, including, as one of six basis propositions: "The hard procedural bars-pertaining to statutes of limitation, availability of administrative remedies, and time limits for filing an appealapply equally to represented and unrepresented litigants. Some of the cases do not support this principle, but the majority do. These procedural bars are fundamental rules governing the legal process. For the most part, appellate courts are uncomfortable applying them differently to different parties for any reason-and particularly not because they are or are not represented by counsel."). 


\section{IMMIGRATION ATTORNEYS AND ADVOCATES:}

\section{a. Argue that Undergoing a Credible Fear Interview Constitutes Filing for Asylum}

In the absence of further reform by EOIR or USCIS, which seems incredibly unlikely in light of the election of Donald Trump, whose campaign was in part fueled by anti-immigrant rhetoric and vitriol, attorneys must now, more than ever, continue to zealously advocate for asylum seekers affected by the one-year filing deadline and the immigration court backlog.

Specifically, attorneys must continue to argue interpretations of the statutes and regulations, as Yesenia's attorney did, that an individual who has undergone a credible fear interview has essentially applied for asylum. INA $\S 208(1)(a)$ provides that an application for asylum can be made "in accordance with this section or, where applicable, section 235(b) of this title." ${ }^{252}$ The one-year deadline, codified under INA $\S$ 208(a)(2)(B), provides that absent extraordinary or changed circumstances exceptions, $\S 208(1)$ shall not apply unless the application for asylum is made within one year of the applicant's arrival in the United States. ${ }^{253}$ The expedited removal provisions of the statute, codified under INA $\S 235(\mathrm{~b})$, state that when an inadmissible alien seeking admission "indicates either an intention to apply for asylum under section 208 of this title or a fear of persecution, the officer shall refer the alien for an interview by an asylum officer under subparagraph (B)." ${ }^{254}$ INA $\S 235$ (b) provides the process for asylum officer consideration and review of the credible fear interview and no application form is mentioned or required in that process. ${ }^{255}$ Therefore, once an individual states that she is afraid to return to her country of origin, she should be deemed an applicant for asylum.

The argument has been made that under the plain language of the statute, a request for or referral to a credible fear interview under INA $\S 235(\mathrm{~b})$, made within the first year after entry, constitutes an application for asylum. ${ }^{256}$ As such, any individual who has undergone or even simply requested a credible fear interview has met the one-year deadline. While this argument has merit, the immigration judge and the BIA in Yesenia's case discussed in Part III, squarely rejected this reasoning, ${ }^{257}$ and the argument has yet to be ruled upon in any

252. INA § 208(a)(1), 8 U.S.C. $§ 1158(a)(1)$ (2012) (emphasis added).

253. Id. $\S 208(\mathrm{a})(2)(\mathrm{B})$.

254. INA $\S 235(\mathrm{~b})(1)(A)(\mathrm{ii}), 8$ U.S.C. $\S 1225$ (b)(1)(A)(ii) (2012).

255. Id. $\S 235(\mathrm{~b})$.

256. Yesenia IJ Decision, supra note 163, at 13-16.

257. Id. at 18 . 
precedential decision nationwide. Unless and until the backlog disappears, the one-year deadline is eviscerated, or DOJ and DHS issue regulations clearly recognizing an extraordinary circumstances exception for a lack of notice and knowledge of the deadline, attorneys must continue to engage in aggressive advocacy for clients who missed the deadline due to a lack of notice and any meaningful opportunity to file.

\section{b. Increase Legal Representation of Asylum Seekers}

Prior to the immigration court backlog, attorneys helped to ensure that an individual met the one-year deadline by timely filing their asylum applications with the asylum office or in immigration court. In the era of the immigration backlog, combined with the rule requiring in-court filings, attorneys engaged in the technical and cumbersome steps in an effort to preserve asylum eligibility and prove attempts to timely file. The September 14, 2016 EOIR announcement is welcome news for immigration attorneys, who can now simply file their client's application with the court window to both start the clock for employment authorization purposes and to meet the one-year deadline. Indeed, attorneys may be the group who benefit most from the recent policy change. Hopefully, attorneys will now be freed up to take on additional representation as they will no longer expend the same amount of time and resources simply acting to preserve asylum eligibility.

Increased legal representation in asylum cases may also help to alleviate the immigration court backlog by increasing court efficiency. ${ }^{258} \mathrm{~A}$ recent nationwide study of access to counsel in

258. The National Association of Immigration Judges (NAIJ) has made clear that representation increases efficiency in immigration court. In a letter to Senate majority leader, Harry Reid, and Senate minority leader, Mitch McConnell, the NAIJ explained:

It is our experience that when noncitizens are represented by attorneys, Immigration Judges are able to conduct proceedings more expeditiously and resolve cases more quickly. Judges have found that cases with legal representation generally 1) reduce the number and length of proceedings for benefits for which individuals are ineligible; 2) generally require fewer continuances for preparation (including when applications must be processed by other agencies); 3) obviate appeals based on lack of understanding of legal rights or concerns about fairness; 4) take less hearing time for judges because they are better researched and organized; and 5) tend to reduce the number of futile claims which utterly lack a basis in law.

See Letter from Dana Leigh Marks, President, Nat'l Ass'n of Immigration Judges, to Harry Reid, Majority Leader, U.S. Senate and Mitch McConnell, Minority Leader, U.S. Senate on Special Concerns Relating to Juveniles in Immigration Court (July 22, 2014),

http://www.immigrantjustice.org/sites/immigrantjustice.org/files/NAIJ Senate Ltr ens uring fairness to juveniles 201407 22.pdf [https://perma.cc/88NC-DCTR]; see also 
immigration court concluded that having counsel increases immigration court efficiency, ${ }^{259}$ along with the rates of release for detained individuals ${ }^{260}$ and appearance rates following release. ${ }^{261}$ Indeed, recently a spokesperson for the Executive Office of Immigration Review itself stated, "[i]n general, legal representation enhances the effectiveness and efficiency of immigration proceedings." 262

Srikantiah et al., supra note 122, at 210 (citing Letter from Hon. Dana Leigh Marks, President, Nat'l Assoc. of Immigration Judges (Mar. 22, 2013)).

259. Donald Kerwin, Revisiting the NeEd FOR APPOINTED Counsel, MigRATION POL. INST. 1 (2005), http://www.migrationpolicy.org/research/revisitingneed-appointed-counsel [https://perma.cc/SHV9-ETV3] ("Legal representation benefits immigrants, but it also serves the government's interest by promoting better-prepared cases, more efficient proceedings, shorter detention periods, and correct legal decisions."); M. Margaret McKeown \& Allegra McLeod, The Counsel Conundrum: Effective Representation in Immigration Proceedings, in REFUGEE ROULETTE: Disparities in Asylum AdJudication And Proposals fOr Reform, 286, 289 (Jaya Ramji-Nogales et al. eds., 2009) (“At every stage of immigration proceedings, as in other areas of litigation and adjudication, the presence of competent counsel improves the efficiency of case processing and the administration of justice."); Eagly \& Shafer, supra note 113, at 5 (citing Lucas Guttentag \& Ahilan Arulanantham, Extending the Promise of Gideon: Immigration, Deportation, and the Right to Counsel, 39 Hum. RTS. 14, 16 (2013) ("Advocates have also shown that speedy appointment of counsel can save substantial detention costs if detained immigrants have qualified lawyers to promptly assess their claims.")).

260. AM. BAR ASS'N, ENSURING FAIRness AND DUE Process IN IMMIGRATION PROCEEDINGS 2008 , http://www.americanbar.org/content/dam/aba/migrated/poladv/priorities/immigration/2 008dec_immigration.authcheckdam.pdf [https://perma.cc/T3GA-7PY9] (“[L]egal representation also benefits the government and the administration of justice through . . . fewer requests for continuances and shorter periods in detention at significant financial savings."); NAT'L IMMIGRATION LAW CTR, BLAZING A TRAIL: THE FIGHT FOR Right to Counsel in Detention AND BEyond 9-11 (2016), https://www.nilc.org/wpcontent/uploads/2016/04/Right-to-Counsel-Blazing-a-Trail-2016-03.pdf [https://perma.cc/6Y3Y-PG47] (citing U.S. DEP'T. OF Justice, Cost SAVINGS Analysis - The EOIR Legal Orientation Program 2 (2012), https://www.justice.gov/sites/default/files/eoir/legacy/2013/03/14/LOP_Cost_Savings_ Analysis_4-04-12.pdf [https://perma.cc/CDR9-4FNN]); Eagly \& Shafer, supra note 113 , at $\overline{69}-72$;

261. AM. BAR ASS'N, supra note 260, at 2 ("[L]egal representation also benefits the government and the administration of justice through improved appearance rates in court . . . ."); Eagly \& Shafer, supra note 113, at 2, 59-75; see also Srikantiah et al., supra note 122, at 226, 230 (reporting that detained immigrants in removal proceedings in Northern California were able to obtain bond seventy-one percent of the time when represented by attorneys working for area non-profit organizations. The study also reported that where non-profit attorneys represented detained immigrants, they received immigration relief allowing them to remain in the United States thirtythree percent of the time, a striking statistic compared with only eleven percent success in remaining in the United States for unrepresented detained individuals).

262. Fernanda Santos, It's Children Against Federal Lawyers in Immigration Court, N.Y. TIMES (Aug. 20, 2016), http://www.nytimes.com/2016/08/21/us/inimmigration-court-children-must-serve-as-their-own- 
Scholars and advocates have also suggested that appointing government-funded counsel to asylum seekers would be "fair to lowincome asylum applicants with complex but valid cases" and "help to deter fraudulent applicants from pressing their claims." 263 Calls for government-funded appointed counsel for immigrants in removal proceedings, and more specifically asylum seekers, have made their way into recent proposed legislation. ${ }^{264}$ Advocates are also pushing through class action litigation for guaranteed legal representation for some of the most vulnerable groups, including children ${ }^{265}$ and mentally incompetent immigrants ${ }^{266}$ in removal proceedings.

Until the government funds appointed counsel for all asylum seekers-or, in the very least, a subset of the most vulnerable asylum seekers-attorneys should individually aim to take on pro bono representation of asylum seekers and to encourage their networks and peers to do the same. ${ }^{267}$

lawyers.html?mwrsm =Email\&_r=0 [https://perma.cc/UT5D-469M]) (quoting EOIR Spokesperson Kathryn Mattingly).

263. Philip G. Schrag, Offer Free Legal Counseling to Asylum Seekers, N.Y. Times (July 12, 2011, 11:10 PM), http://www.nytimes.com/roomfordebate/2011/07/12/how-can-the-asylum-system-befixed/offer-free-legal-counseling-to-asylum-seekers [https://perma.cc/CLY6-MCA8]; see also AM. BAR Ass'N, supra note 260, at 2 (stating that legal representation deters frivolous claims); Bill Frelick, Room for Debate: The Right to Representation, N.Y. TIMES (July 12, 2012, 11:10 PM), http://www.nytimes.com/roomfordebate/2011/07/12/how-can-the-asylum-system-be-

fixed/asylum-seekers-the-right-to-representation [https://perma.cc/T9PK-GTMT] (arguing that giving asylum seekers the right to funded appointed counsel would undermine fraud and also stop asylum fraud from "costing the government by clogging the system with erroneous decisions and inefficiencies").

264. Recently, for example, Senator Harry Reid proposed the Fair Day in Court for Kids Act of 2016, which would provide counsel for immigrant children in proceedings. S. 2540 114th Cong. (2016). The Refugee Protection Act of 2016, S. 3241, 114th Cong. (2016), and the Senate Border Security, Economic Opportunity and Immigration Modernization (SBEOIM) Act of 2013, S. 744, 113th Cong. (2013), make similar proposals. Section 3502 of SBEOIM focused on "improving immigration court efficiency and reducing costs by increasing access to legal information," including appointing counsel to unaccompanied children, individuals with serious mental disabilities, and "other particularly vulnerable immigrants" in immigration court if counsel is "necessary to help ensure fair resolution and efficient adjudication of the proceedings" and allowing immigration judges to appoint government funded counsel in other instances at her discretion. $I d$.

265. See J.E. F.M. v. Lynch, 983 F.3d 1026 (9th Cir. 2016) (certifying the class of asylum-seeking children in the Ninth Circuit).

266. See Franco-Gonzalez v. Holder, No. CV 10-02211 DMG (DTBX), 2013 WL 3674492 , at $* 10$ (C.D. Cal. Apr. 23, 2013) (ordering that EOIR and DHS must provide mentally incompetent immigrants unable to represent themselves in California, Washington, and Arizona with legal counsel in removal proceedings).

267. Following the results of the November 2016 Presidential election, inducing fear and heartbreak in immigrant communities, there has been an outpouring 
One consideration in arguing in favor of increased legal representation for asylum seekers is, of course, that the simple fact of representation does not ensure high-quality, competent representation. Indeed, the New York Immigrant Representation Study conducted an anonymous survey of New York immigration judges and made clear that private practitioners-who provide ninety-one percent of all immigration representation-were rated significantly lower than other categories of providers, including law school clinics, pro bono counsel, and nonprofit organizations. ${ }^{268}$ Indeed, immigration judges surveyed reported that "[n]early half of all representatives are not prepared and lack even adequate knowledge of the law or facts of a particular respondent's case." 269 While concerns over the general competence and quality of the immigration bar overall are not new, new data regarding this problem has been recently published suggesting that inadequate representation is exceedingly common. ${ }^{270}$ Concerns about the quality of representation, however, do not justify failing to provide or attempt to provide representation. ${ }^{271}$ Rather, the prevalence of substandard representation should be a call to action for funders and specialists alike

of support in the legal community, including a spoken willingness from attorneys of all areas of specialization to train and undertake pro bono representation of immigrants in need. One can only hope that these words and sentiments propel like-minded concrete action.

268. Steering Comm. of the N.Y. Immigrant Representation Study Report, supra note 122 , at 389 .

269. Id.

270. See Eagly \& Shafer, supra note 113, at 8 (questioning how complete attorney representation in removal proceedings truly is-and finding that "only $45 \%$ of immigrants we count as 'represented' had an attorney appear at all of their court hearings"); see also NAT'L IMMIGRATION LAW CTR., supra note 260, at 26-27 (recommending that representation provided through proposed universal representation models for individuals in removal proceedings must be "high quality and supported by adequate resources"); Steering Comm. of the N.Y. Immigrant Representation Study Report, supra note 122, at 389 (immigration judges surveyed gave a "blistering assessment" of immigration representation, reporting that half of the time representation did not meet a "basic level of adequacy"); Careen Shannon, Immigration is Different: Why Congress Should Guarantee Access to Counsel in All Immigration Matters, 17 UDC/DCSL L. REV. 165, 200 (2014) ("[T]he representation many licensed attorneys provide to immigrants is often substandard.").

271. But see Benjamin H. Barton, Against Civil Gideon (and for Pro Se Court Reform), 62 FLA. L. REV. 1227, 1274 (2010) (arguing that the movement to extend universal representation to the civil arena is deeply misguided and instead, pro se court reform would be a more effective and realistic solution); Jessica K. Steinberg, Demand Side Reform in the Poor People's Court, 47 ConN. L. REv. 741, 751 (2015) (critiquing calls for full legal representation in the civil setting as impractical and unlikely to substantially improve fairness for unrepresented individuals in the civil context). The Author would note that the statistics on the positive effects of representation in immigration court are more persuasive than those regarding pro se and represented litigants in other civil contexts. 
to engage in training and engaging the wider legal community in handling these often complex-but incredibly compelling-cases. ${ }^{272}$

\section{c. Outreach and Information Sharing with Asylum Seekers}

To facilitate increased representation rates for asylum seekers, and, in the absence of representation, to ensure knowledge and understanding of the one-year bar, attorneys and advocates must mobilize to reach asylum seekers. ${ }^{273}$ Because the recent policy change does nothing to remedy the lack of notice of the one-year bar, asylum seekers must be informed of their obligation to file an asylum application within one year after arrival.

This outreach and education could be achieved through a number of measures. Various non-profit organizations across the country have implemented pro se I-589 Application for Asylum lodging, or now, filing workshops. ${ }^{274}$ Attorneys could explore offering consultations for pro se asylum seekers at a reduced fee, or partnering with non-profit organizations to participate in I-589 filing workshops. Advocacy groups and those working with asylum seekers should take action to publicize the deadline and the rule change to maximize the number of asylum seekers informed of the deadline and their opportunity to file their application at the court window. ${ }^{275}$

272. These efforts are already underway. In particular, the new Center of Excellence, led by Stephen Manning and supported by others, focuses on "changing the ecosystem" for asylum adjudication at difficult jurisdictions for asylum seekers, piloting in Atlanta, Georgia, by providing robust training and mentoring for attorneys handling asylum cases. See Center of Excellence: Core Asylum Curriculum, InNovation Law LAB, https://innovationlawlab.org/center-of-excellence/ [https://perma.cc/QK46MUAD] (last visited Nov. 11, 2016).

273. Jeffrey Selbin et al., Service Delivery, Resource Allocation, and Access to Justice: Greiner and Pattanayak and the Research Imperative, 122 YALE L.J. OnLINE 45, 60-61 (2012), http://www.yalelawjournal.org/forum/service-delivery-resourceallocation-and-access-to-justice-greiner-and-pattanayak-and-the-research-imperative [https://perma.cc/5AYK-UGHE] (stating that self-help reforms and court simplification efforts have become more than a "stopgap" and, in the absence of access to counsel, have "become significant features of the access to justice landscape in their own right").

274. These organizations include CARECEN, Los Angeles; Casa Marianella, Austin; U.N. Local, New York; Allegra Love, Santa Fe; the San Francisco Immigrant Legal \& Education Network, San Francisco; New Sanctuary Coalition of NY, New York City; and Tahirih Justice Center's Houston office. See E-mail from Michelle Mendez, Training \& Legal Support Staff Att'y, Catholic Legal Immigration Network, Inc., to author (Sept. 27, 2016, 1:17 PM) (on file with author).

275. Catholic Legal Immigration Network, Inc. (CLINIC) is putting together a pro se resource sheet following the Sept. 14, 2016 EOIR rule change in Spanish to assist asylum seekers in navigating the new rule. See id. 


\section{CONCLUSION}

The shortage of pro bono resources and the crisis in representation for many individuals and families seeking asylum protection urges a more comprehensive solution than the simple and limited policy change announced by EOIR in September 2016. A sweeping statutory fix eliminating the one-year deadline to apply for asylum, while an ideal solution, seems untenable in the current political climate. Likewise, an immediate resolution of the immigration court backlog is unlikely.

Averting an avoidable humanitarian disaster, therefore, depends on quick action by EOIR and USCIS to implement the administrative and regulatory solutions proposed in this Article, which will maximize the positive impact of the already-announced EOIR September 2016 policy change. Leaving the system in disarray with no uniformity in decisionmaking on this issue throughout the nation is simply unacceptable. Unless this problem is resolved, the United States government risks leaving otherwise-eligible asylum seekers with inadequate protection and no path to integration. Failure to give this population of individuals, who will likely never be able to return to their country of origin, the opportunity to integrate creates insecurity for individuals who deserve a meaningful second chance in life and an opportunity to contribute to and benefit from participation in American society.

Simply put, DHS, including USCIS and EOIR, must immediately begin issuing advisals regarding the requirement to file for asylum within one year to any individual who makes it clear that he or she intends to seek asylum and comes to the attention of one of the agencies. EOIR must further take steps to remedy the inequity they have inadvertently created for pro se versus represented asylum seekers. These steps include issuing clear instructions for immigration judges regarding lack of notice combined with the lack of a hearing prior to one year. EOIR must make clear these two factors combined constitute an extraordinary circumstance, and, further, that expressing a fear of return or undergoing a credible fear interview should deem an individual's application for asylum filed for one-year bar purposes. In the long-term, DHS and EOIR should initiate the process of amending their regulations to enumerate additional extraordinary circumstance exceptions to the one-year deadline. This should include an exception for an asylum seeker who lacked notice of the deadline and a court hearing scheduled within one year. Failing these additional steps to be taken by government agencies, advocates and attorneys must work to increase asylum seekers' knowledge of the one-year filing deadline and the new mechanics for meeting that deadline. These concrete and entirely feasible measures will avoid thousands of asylum seekers facing the same fate as Liana and Yesenia, who remain in limbo awaiting further review of the erroneous initial decisions in their cases. 